\title{
EFEECTS OF REPEATED GALVANIC STIMULATION THROUGH THE HEAD ON THE LABYRINTHINE REFLEXES IN FOWLS
}

\section{By}

\section{S. AOKI}

From the Department of Otorhinolaryngology, Gifu Medical School. (Director: Prof. T. Fiukuda M.D.)

The heads of three leghorns were stimulated galvanically ( $4 \mathrm{~m} \mathrm{~A} .8 \mathrm{~V}$.) for five minutes in two opposite directions passing through both external auditory meati every day for two weeks. The labyrinthine reflexes observed during and after galvanization showed marked changes at the end of two weeks as compared with those prior to the start of stimulation, as follows:

1. The head which had deviated toward the side of anode during galvanization at the beginning, became to deviate in the opposite direction i.e. to the side of cathode at the end of two weeks.

2. Galvanic nystagmus and especially after-galvanic nystagmus decreased in number of jerks as the day of stimulation went on.

3. Ataxia during and after galvanization decreased with days of stimulation and almost disappeared at the end of two weeks.

4. It is very interesting that leghorns which had been stimulated solely with galvanic current for two weeks showed "kinetic labyrinthine reflex" at the first Báràny rotation, i.e. deviation of the head during rotation in the direction of rotation after normal deviation, the reflex previously reported by Fukuda as a functional development of labyrinthine reflex with rotatory training.

\section{反覆頭部通電による迷路反射の変化}

岐皁医大耳鼻咽诶科教室（主任：福田精教授）

$$
\text { 能手青李杳茂 }
$$

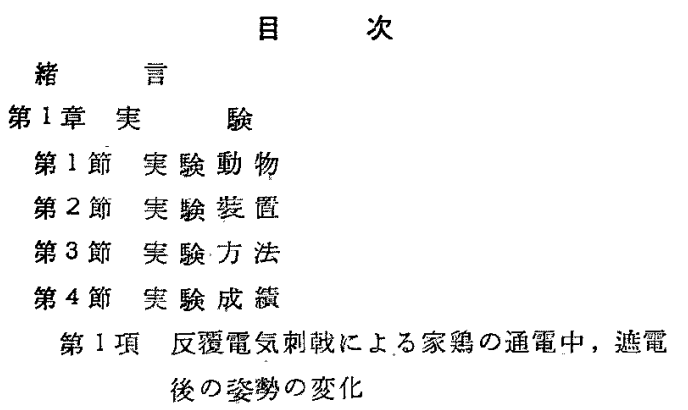

A. 電気刺戟初回の家彩

a) 除極右耳，榢㥛在耳の第合

b) 陰埂左耳，汾極右耳の埸合

B. 電気刺韩 14 日目の家丽 a）阷極右耳，陽極左耳の場合

b) 除極左耳, 陵極右耳の場合

C. 婵日電気刺戟第 14 日目の家㗖之電気刺戟初 回の家鹞の姿勢の比校

第 乙项 反嗄電気刺戟による家鶂の通䉓中，遮電 後の頭振

A. 通電中の頭振の变陲

B. 電流性後頭振の变陲

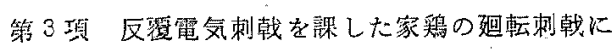
対する反射の变化

$\begin{array}{lll}\text { 第2 章 } & \text { 総 } & \text { 括 } \\ \text { 第3 章 } & \text { 䒺按 }\end{array}$




\section{緒}

趈転刺㦸を連日動物に課すると，廻転性後腿振（postrotatory nystagmus）は日毎厄低減する。

この事実は星野1)の最初の赧告以来，福田 2)3，桧 ） 3）等に上り，種々の䀧物にて数多くの報告がなされて いる. 併し, この迴転性低後腿振 (postrotatory hypo" nystagmus）の成立に関する解釈は，末ちをちで未だ 一定しない，例えば，三半規管のあらわす諸反応行，强 い刺战が繰返へして与号られると減退して行くものであ

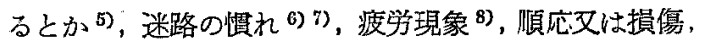
あるいは中枢作用 4，等々漠然と解されている。

最近新しい廻転法 cupulometry 9) を考案した域值以 下迴転理論を主張寸る北欧の学者は，この低隇江強い迴 标刺战のため，前庭迷路が損傷（damage）された故な り之新説を唱えているり．蓋しこの一派の学者は迴転後 感覚（迴転停止後な打迴転と逆方向に迴転するように 感じる感覚) を迷路感覚として重視するので，彼等の云 5 所謂, 迷路感覚と表裹一体をなす䞟転性後眼振の低減 は損傷に上る機能の低下と解さ极ば，理諞が成立しない、 かららである。

福田”及びその協同研究者は，この低減に 関して全 く新しい解釈をなし，これを稁付ける実駼を十数年来報 告している. 即ち迴転涉後腿振及び伴われる後感覚は， 迷路本来の反射や感覚ではなく，末だ嘗て動物及び人が 受けたことのない passive の迴転を数十回にわたり課 せられるため，迷路はこれに応じ切れず平衡破綻 ataxia 老きたすこの迷路性平衡失調の現われが，後腿振並び に後感覚である．従つて迴転の連日加重により低後眼振 をきたすのは，迷路性平衡失調が克服された，迷路性平 衡機能の向上之解する.

その実証として，日頃迴転運㲜を身体に課しているス ポーッマン、パイロット，バレリーナ多多数検查し，彼 等が一様炕正常人平均值上り著しく低い、低後腿振定示す 事を明らかにし，のみならず初めて人について実跧的に 低後眼振の成立を明らかにした ${ }^{10)}$. 即ち小学生多数に 運日 active 並びに passive の迴転運動を課す事によ り，月余の後は著しい低後腿振をきたすと同時に，非常 に平衡機能，運動機能を向上せしめ得て，湢田の理論を゙ 夏に裹付けると同時に，この事実をるつて迴枟の加重を 訓練 training と呼んだ。

又最近福田及びその協同研究者である我々は，画転 ${ }^{8)}$ の連日加重により低後眼振をきたすと同時に，迷路性平 衡㙨能が著しく向上する事を初めて具体的に，客観的に
これを明らかになし得た。即ら一般に動物並びに人を䢙 転椅子にて passive に迴転すると，迴転開始と同時に眼 及び頭部は迴転と逆方向に偏倚し，nystagmus を迴転 方向に発来しつ〉，廻転中を通し，この逆方向への偏倚 が続くこの偏倚は古くから知られている事実で normal deviation と呼ばれ，迴転中の迷路反射の重要な 指標と観なされている．乙かるに迴転を連日加重すると 低後眼振をきたすのみならず，この normal deviation を超える迴転中の新しい高次の反射が迷路性に形成され る。即ち迴䩪を連日加重した家鴊に抹いて，迴転当初は 必蛮迴転と逆方向に頭部は偏倚し normal deviation の 姿勢を取るが，数秒にして頭部は中央に戻り，更に遠心 功抗して椅子の迴転と同方向に䁚部は向い偏倚し，迴 葓中，この迴轱方向へ頭が固定される。第1图に図示す

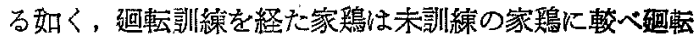
中の頭位が全く対象的，鏡像ななして迴転方向へ向つて いる.

頭部が回転方向へ向らと云う従来全く未知の新しい反 射の形成を福田 ${ }^{32}$ は kinetic labyrinthine reflex と名 付け，慣れぬ passive の迴転に応ずる動的の迷路性平 衡反射が成立した事を明らかにし，これに対応して從来 の normal deviation static labyrinthine reflex と呼んだ。蓋し静止より廻転刺㦸を受けた場合，原位置 を維持せんとする反射之辂釈したからである。

以上の吝く迴転の連日加重による低後眼振の真の生 理学意義は 平衡機能, 迷路機能の向上として kinetic labyrinthine reflex の成立を裹付けとして,こつに我々 により漱く明らかにされた。従来，生理学に又臨床によ く用いられている迷路刺钱は，以上の廻転刺㦸の他に温 度刺战，電気刺战が数えられる。こつに報告する著者の

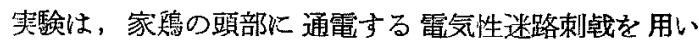
た。この電気刺钱の連日加重により家鷄に起る頭振の持 紽時間及び打数がいかに推移するかのみならず，家彩の 姿势がいか江変化するかを観察目標とし実験を行つた．

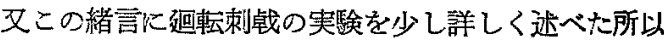
を明らかにして置きたい、温度刺战にて起る nystagmus は，方向は一定し途中で変化しない，且つ温度刺战を連 日加重すると迷路反射，即ち温度性眼振はやはり低減の 傾向を示すが甚た複雑な多数性を示し，且つ屡々整死し て（白木 - 竹内 [未発表]）迴檕刺㦸の加重の健康さと は藷しく異る成續を示す しかるに通電，遮電時の電気 刺㦸は迴転刺战と甚だよく似た成績を示す 即ち通電と

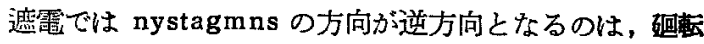


中と迴転後に全く等しく，又遮電後なお nystagmusを 活愿にみるのは迴転停止後更に後腿振が発来するのと全 く同じく，刺战が除去されたあとの後反応である．本論 文中洋述する如く，刺㦸の加重によつてる雨者は全く 酷似の成結を示す 故に通電刺㥂を連日加重し終えた家

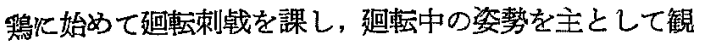
察した。その結果，敬くべきことは，廻轱の加重により 初めて得られる kinetic labyrinthine reflex が電気刺 战のみを連日課した家䳝において成立していた事を確夷 明らかになし得た。これをすつて，これを観れば，従 来迷路生理は勿諭，臨休において等閒視されてさた電気

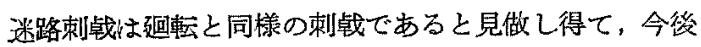
この新しい観点に立ら更に検纾，䂺究を要する事を痛感 する・

\section{第 1 章 実戨}

第 1 節 実験動物

成熟家鷄（白色レグホン）三羽を用いた。

第 2 節 実跒装置

平流刺战発生粒置として第 2 图以示寸如き，イト一式 マスキーレーター D 型を使用した. 丽桠は厚さ $0.2 \mathrm{~mm}$ ， 殖径 $18 \mathrm{~mm}$ (電極面積的 $2.54 \mathrm{~cm}^{2}$ ) の銅製円板で，これ に綿を当て布で覆つた同大の電極 2 個を用いた。

第3節 実橎方法

絆創高にて两眼を选蔽し視賞を奪つた家鵎を何等束縳 する事なく，第 3 図の如く鋼鉄製の止り台（家框の止る 部分のみは布が巻いてある)の中央に止らせる，この状 態にて，上述の同大の電極を生理的食塩水で充分に濡り した後，家鶏の両側耳部 (外耳道部)にゴムで密着さ せそその上を面に紏創宫で固定した。

次ぎ 4〜4.5mA, 8〜 10V の平流を，始め右耳部に 路極を置き，左耳部に 陽極を 置さて 5 分間通電し，10 分間の間滆を置いて後に，左耳部に陰極，右耳部に陽極 を置いて 5 分間，合計 10 分間の両極電気刺战を負荷し た。この通電量は稻々の検索の結果, 明瞭な反応を発来 させるのに最す適当な必要量であることを数次の寒験に より磪かめたので用い，通電中及び遮電後の家䳕の姿勢 (主として頭部, 项部, 身喿幹)の変化定 観察し, 発来す る頭振を計測した。計測は陰極右耳，陽極左耳の場合， 猞極左耳，陽極右耳の場合，各々について姿勞の変化， 頭部の偏倚方向之角度，頭振数，頭振持続時間を 10 秒 㮘に連日記戴した。観察に当つては刺钱発生装㯰を操作 する者之, 止り台の雨側に 2 人の检者が立ち,一人は家 鵎の頭振数を肉眼にて数え，今一人は家鴊の頭部，頸

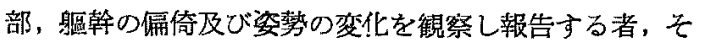

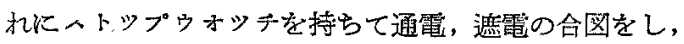
前 2 者が報告する頭振数を 10 秒毎に記戴し，頭部，頸 部, 身翰の偏倚及び姿蔆の状熊を記戴する者と, 計 4 人 の検者にて施行した。なお，雨電開始時は直角電流刺战 である. 以上の如き条件で連日 14 日間反覆電気刺战を 傎荷した家鷄と，正常無処置の家鵴とを止り台上で電気 刺㦸を負荷し，而者の姿勢を比䡥した。

次に迴整椅子の上に止り木を設置し，その上に絆創悟 で遮眼した電気刺㦸前の家鹞を乗せ，20 秒 10 迴転の迴

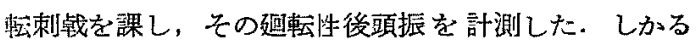
後，同家䲧に連日14日間反覆雪気刺戱を顀荷して同様 の廻転制㦸を課し，その迴転泩後頭振々，前者のそれと を比较した。最後に連日 14 日間反覆電気刺㦸を偩荷し

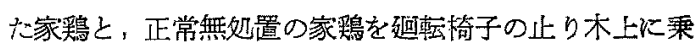
せ，紏創謷にて遮眼し，20 秒 10 趣転の迴転刺㦸を課し

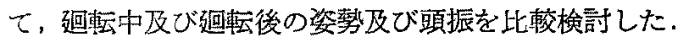

第 4 節 実驗成續

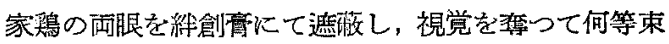
縉を加党る事なく，第3図の如く止り台上に乘せた。電

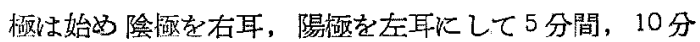
間の間滆置いて，陰㥛を左耳，陽極を右耳にして5分 間, 各々 4 4.5mA, 8〜10V の病流で計 10 分間を1日 の刺战量として連日 14 日間負荷した，毎日の観察は通 電中の姿勢の変化, 頭部偏倚の方向と府度, 頍振数の計

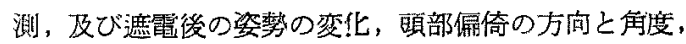
頭振持:続时間, 頭振数の計測を 10 秒間隔にて記戴した. な和，実験に用いた3羽の白色レグホンは電気刺韩に対 乙原則的に同様の反射学表わしたので，No.1 白色レグ 水ンの実験成績を詳細に述ぺ，No. 2, No. 3 の白色レ グ㇇ンはその概略を述べる，又電極の位置は㓌極を在 耳，陽極を左耳の場合と，陰㥛を右耳，陽極を左耳の場 合は，各々頭部，頸部，身區幹の偏倚方向，頭振の方向が 逆になるのみで，偏倚の角度，頭振数，渠勢の変化は大 差なかつたので, 主として陰極右耳，陽㥛圭耳の埸合を

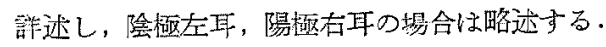

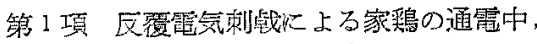
遮需後の染勢の变化

No.1白色レグホン

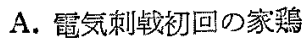

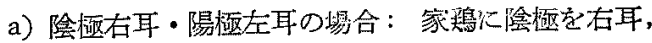
陽洒を左耳にして，4mA，8V の直角電流刺钱にて通電

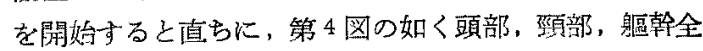


体が亡側，即も，陽極側（電流と反対方向）に約 60 度偏 倚し平衡失調状湆となるが2〜3秒間翼をバタつかかせ， 雨翼を拡げて辛らじて止り台上炕止り，ついで急速相が

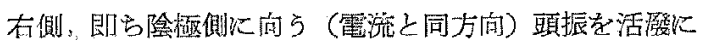

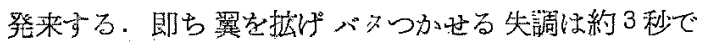

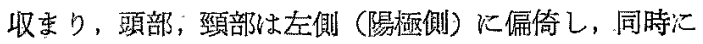
頭振を右側（隆極側）飞発来乙，両脚党屈して身區幹を止 り台に接し，遮要する迄この姿勢をとり頭振を発来す る. 5 分間の通電の後, 遮麗する之, 第 5 図の如く, 一 瞬頭部, 頸部, 身幹恃速や力沉右側, 即方陰極側治強く 偏倚 (約90 度)して失調し止り台上から落下せんとする が，両翼をバ只つかせ，両脚を屈し軀幹を止り台上飞接 し，危く止り台上K留をる：ついで通電中と以逆方向の

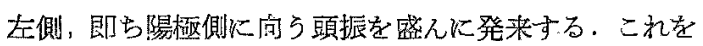
電流性後䌿振と呼吢こと〉する。この頭振は 2 分 12 秒 持続し，83,打を数点た。電流性後頭振終了の後, 家鷅 の頍部，頸部，身區幹は漸次正頭位に㕱る。

b) 陰極左耳，陽極右耳の場合：家鵎に陰極を左耳， 陽㥛を右耳にして，4mA，8V の直庙電流刺晫にて通電 老開始すると直占に，頭部，颁部，身區幹全体が右側（陽 極側)に約 90 度偏倚し2〜3 秒間翼をバタつかせ，耐翼 を拡げて辛うじて止り台上榴る。翼をバタつかせるの

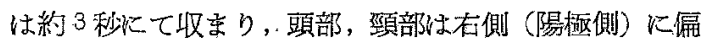

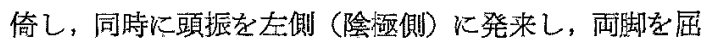
して軀幹を止り台に接し，遮電する迄この姿攀をとり頭 振を発来する：5分間の通電の後，遮電すると，直ちに

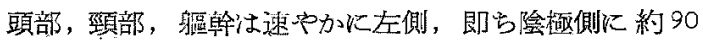
度偏倚して止り台上から落下叫てとするが，雨翼をバン

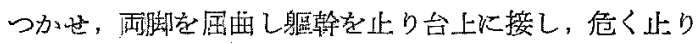
台上に留る。ついで通電中とは逆方向の右側, 即ち陽板 側沟う頙振を盛んに発来する。この電流性後頭振は 2 分 23 秒持続し，87打を数えた。電流性後頭振終了の

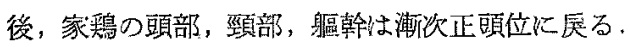

陰極右耳, 陽極左耳の場合屯, 陰䀸左耳, 陽極在耳の 場合も，迴整刺战，温度刺㦸等でよく観察される頭振の 第 2 相は認められない。

\section{B. 電気刺㦸 14 日目の家鵴}

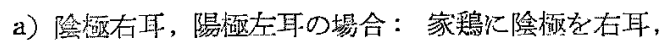
陽極を左耳にして，4mA，8V の直角電流刺战にて通笔

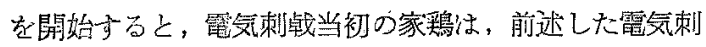
战初回の家鶂と闰じく約 2 3 秒失謂状態をきたし，つ いで頭部，頸部，身區幹は速やがに左側(陽極側) 飞偏倚

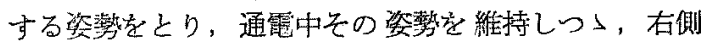

（除極側）に頭振を発来する，遮笔と同时に頭部，頸部，

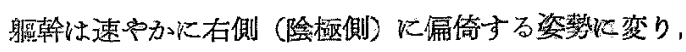
左側（陽極側）に麗流性後頭振を発来させる，迴尝刺 战，温度刺钱等でよく観察される頭振の第 2 相恀出現せ ず，支側へ向ら頭振が消失してから正頭位に厣る。しか

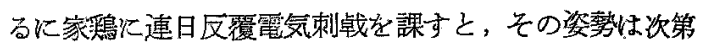
に変化してくる。即ち電気刺战開始より第 14 日目の通 電中及び遮電佬の頭位の変化は，第6図，第 7 図，第8 图，第9困に示寸如くで方る、第 6 図は電気刺戟第 14 日目の陰柾右耳, 陽極左耳儿て通電開始 2 秒後の姿勢て ある.碩部, 頸部, 身區幹は左側, 即ち陽極側へ約 90 度 偏倚しているが，第4图に見られた如き転倒せんとし， 翼を拚げ，辛うじて止り木上に止る失調忋態は全然見ら れない。この姿勢より右側, 即ち陰踈側へ向方頭振を盛 几に発来し, 第 7 図沙見られる如く, 通電開始 2 分後に は頭部, 頸部は反復電気刺㦸前には見られなかつた右㑡 (陰極側) 一約 40 度の偏倚が起る. 即ち通電閏始と共沉 左側(陽極側)へ偏倚していた頭部，頸部は約 5 秒にて正 顕位へ杘り，約 10 秒火て右侧 (院極側) 一偏倚与る:こ の㓌極側へ頭部, 頸部を偏倚寸る時は, 陽極側へ頭部, 到部を偏倚させ，陰極側へ頭振を規則正しく発来させて いたものが，急激に頭振の急速相の方向に大きく頭部を 動かして正頭位に戾る. 正頭位に頭部が戻つてから院極 方向へ再び頚振が発来する。つで再び急激に頭振の急 速相の方向即ち陰極方向へ大きく頭部孛動かし，陰極方 问へ約 60 度頭部を偏倚させる。約 60 度除極方向に頭部 を向け終つてから，院極側へ再び頭振が 発来する。約 30〜20 秒間この頭位を保つて陰極側一頭振を発来させ ているが，漸次頭振を発来さむつ〉正䫄位へ，即号陽極 方向へ頭部が偏倚してくる．乙かる後, 再び頭部が正頭 位に姿ら妨うちに，陰極側に頭部，頸部を偏倚させる。 即ち，陰摄側一頭部，项部が偏倚寸る時には頭振の発来 はなく，偏倚して了つてから陰極側へ頭振を発来する。 かくの如く反覆電気刺啅前沉見られなかつた右側（陰

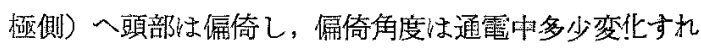

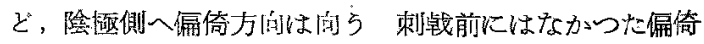
である(第3表).

5 分間通電の後，遮電すると，第8図の如く約 90 度 頭部を陰極側，即占通電中上り更に右側に偏倚さ屿る。 この時第 5 図に見られた如き翼を拡げ，止り台上辛ら じて止る姿勢の失調はない：この姿勢より左側 (陽極側)

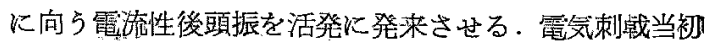
は電流性後頭振が止んでから，徐々に正頭位に復㴆した 
が，電気刺战第 14 日目の家鵎は尷電々 同時に 陰極側一 約 90 度頭部老偏倚させ，陽極側入頭振を発来させ，約 5 秒にて陰極側入約 60 度となり，約 10 秒にて隍極側へ 約 30 度となり，23秒にて正頍位へ戾り，その間頭振 18 打を数えた。この陰極側へ编倚していた頭部が、正中位 (陽極側) 一唇る時には頭振の発来はなく，頭部の偏倚 が安定すると陽極側に頭振を発来する. 即ち，遮電後の 頭部偏倚々, 頭振の関係も, 通電中之同棁に，頭振の急 速相入頭部が偏倚する時は頭振の発来はなく，頭部の偏 倚が安定して了つてから謴振を発来する．しかるに頭振 の緩徐相へ頭部が偏倚する時は頭振を発来しつ〉偏倚す る.

かくの㛎く連日反蕧電気刺钱を負荷する事に上つて変 化する頭位の 5 分間の通電中比洔る時間的推移を第 1 表にて表わして見た。

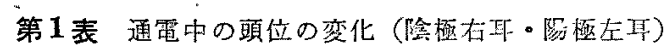

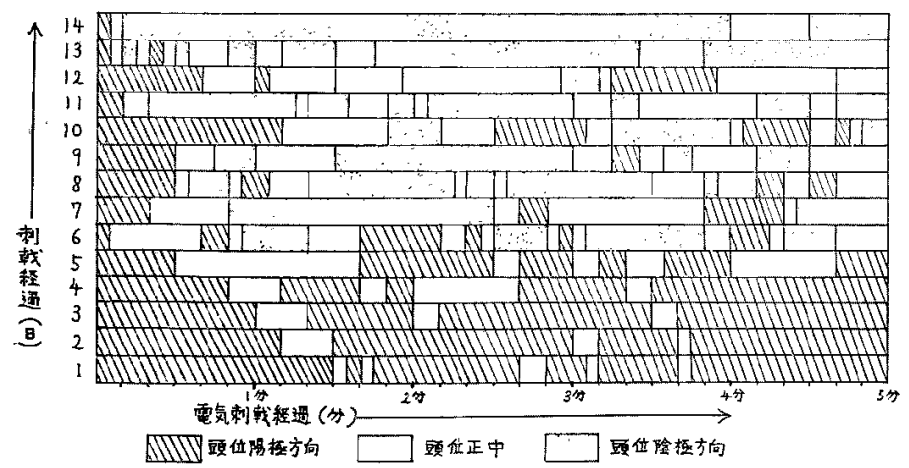

4〜 4.5mA. 8〜 10V. 5 分 No. 1 白色レグホン
倔倚し， 4 分 30 秒にて 40 度陰極側一偏倚し，以後遮電 する迄，陰極側 30 度偏倚させつ入頭振を発来する。第 14 日目になると，通䉓開始之共に陽極側へ頭部，靧部 を 60 度偏倚させるが，3〜5秒にて正頭位となり，約 10

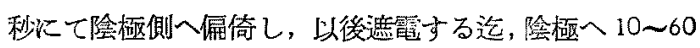
度頭部，頸部を偏倚させ，やはり頫振を発来する。

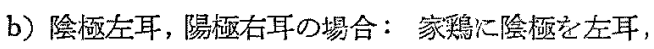

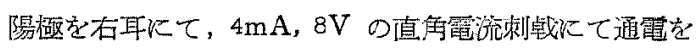
開始すると，電気刺戟当初の家鴔忹，前述した電気刺战 初回の家鶂已同しく約 2 3 秒間転倒せ九として 翼を拡 げ，辛うじて止り木上に止る失調状態をきたし，ついで 頭部，頸部，軀幹は速它か儿右側 (陽極側) に偏倚する 瓷勢をとり，通電中その姿勢を維持しつ〉，龙側（隆極 側）に頭振を発来する。遮電と同時に磁部，頸部，身區幹 心速やか飞左側（陰極側）飞偏倚寸る资藝飞変り，右側 (陽極側) に電流性後頭振を発来させる. 迴転束!战，温度刺战等でよく観察される 頭振の第 2 相は出現せず，右側一向万頭 振が消失してから正頭位に戻る・しかる

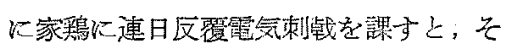
の姿勢の方向性次第に変代してくる.即 ち䉓気刺战開始上り第 14 日目の通電中 及び遮電後の頭位の变行第 6 図，第 7 図，第8図，第9図とその偏倚方向が 正反刘になるのみで全く同様で市る。電

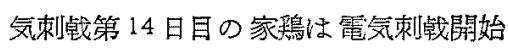
之共江頭部, 頸部, 身幹は右側(陽極 側) 一約 90 度偏筒させるが。電気刺战
電気刺㛺第6日目より，頭位を陽極側から正頭位をこ 之，陰極側に頭位を向ける。電気刺㥂第 14 日目には通 電開始後陽極側一頭部，頸部，身區幹を $3 \sim 5$ 秒間偏倚さ せるが，速やかに正頭位となり，更にこれをこえ除極側 に頭部，頸部は向い，乙れ以後遮電寸る迄，陰極側に頭 部，頸部を偏倚导せ，隆極側へ頭振を発来する。第 3 表 は㓌拯右耳，陽極左耳の瑒合の通電中の頭位の変勤を表 わしたものである、電気刺㦸当初は通電開始と共に陽極 側へ頍部，頸部は 100〜130度偏倚し, 通電開始より1 分にて 60 度となり, 以後遮電する迄，陽極側へ $30 \sim 60$ 度㣯倚させて，隍極側へ頭振を発来する，第7 日目には 通電開始亡共に陽極側入賈部，頸部は 20 度偏倚し，通 電開始より 20 秒にて正頭位となり，1 分にて 除極側 $20 \sim 60$ 度偏倚するが, 2 分 50 秒にて再び偒極側 20 度

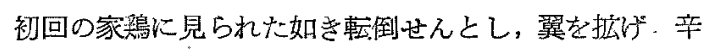
うじて止り木上に止る失調状態恮然見られない。この 姿勢より左側 (院極側) へ向方頭振を盛儿に発来乙, 通 電開始 40 秒後に正頭位へ戻り，60秒後には区覆電気刺 㦸前には見られなかった左側 (陰極側) 一䄪 30 度の盾倚

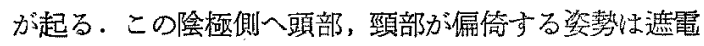
する迄維持され，陰極側入頍振を発来している．かくの

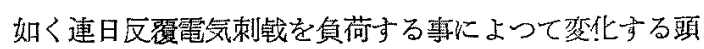
位の 5 分間の通電中に括ける時間的推移を第 2 表にて表

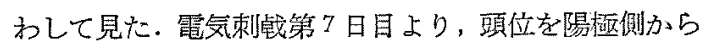
正頭位をこえ，除極側に頭位を向ける、電気刺棹第 14

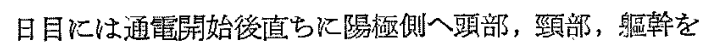
約 40 秒偏倚させるが，速やかに正頭位となり，通電開 始 60 秒後には更にこれをこえ陰極側に頭部，頸部は向 
第 2 表 通電中の䫄位の变化（㓌極左耳・四極右耳）
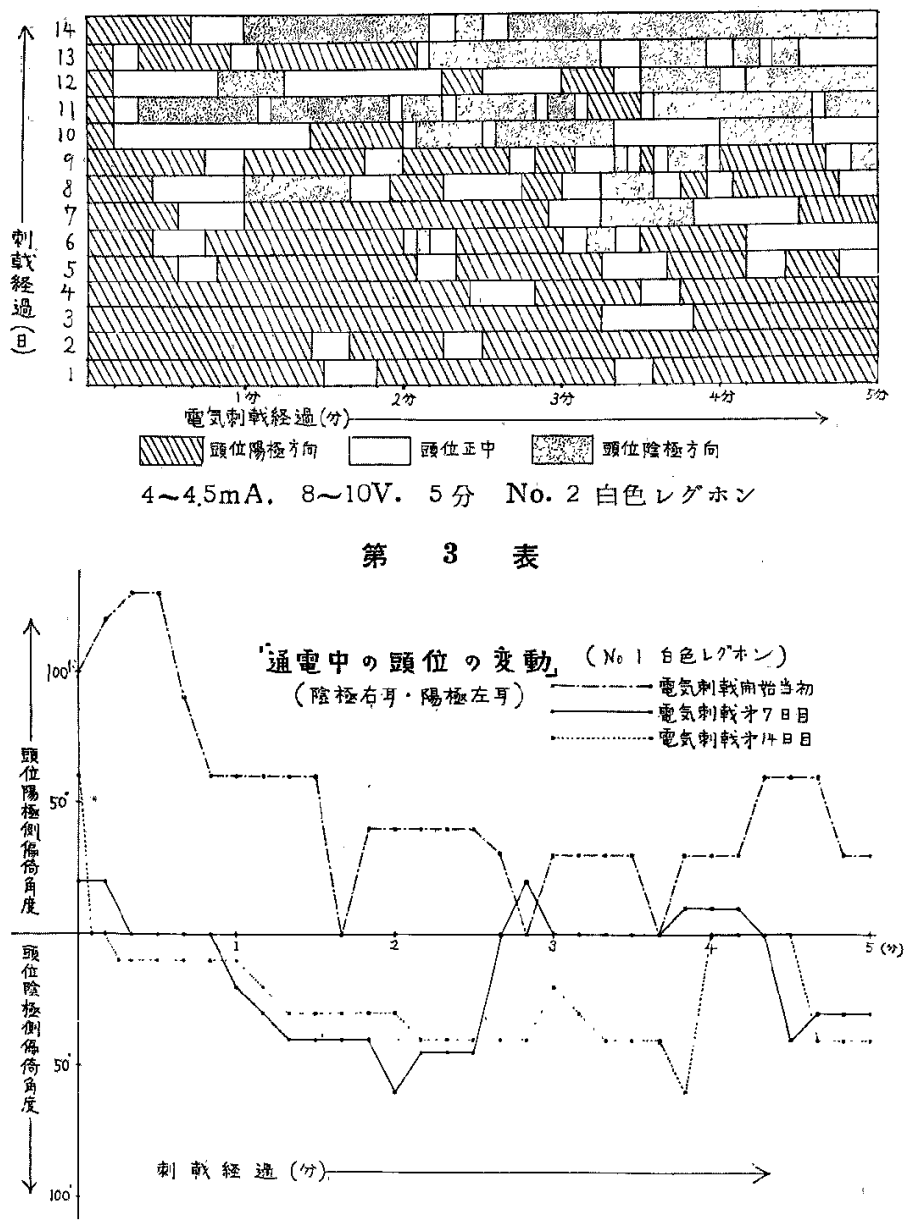

この剌战を連日綵り返えして家舀に負荷 すると，第4图，第5图に見られる 如

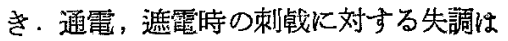
漸次減少し，電気刺㦸第 14 日目の家鴊

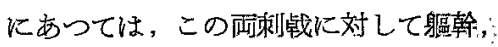
翼の平衡失調は認め難くなり（第6図: 第8図)，通電中，陽椂側入のみ頭部，

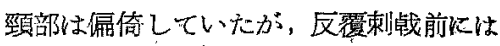
見られなかった院極側への偏倚が起る。 その上，通電中の頍振数及び，遮電後の 頭振持綄時間, 頭振数も激減した。

以上の寒験成績忧 No. 2 白色レグホ ン，Nc. 3 白色レダホン共に同一の頭 部, 頸部 軀幹の偏倚を示し, 姿勢の变 任，頍振発来の状沉等子原則的に同棣の 傾向を認めた。广特，3翏共に14日間

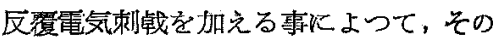
日常行動比著変なく，平衡失調等も全く 認められなかつた。

\section{C. 連日電気刺战第 14 目目の家棉 と電気刺战初回の管鵎の姿熱 の比較}

No. 1, No. 2, No. 3 の白色レグホンは 前述した如く，䉓気刺钱に刘して原則的 に同様の傾向を表方すので，反覆管気刺 战第 14 日目の No. 1 白色レダホンと， 電気刺战初回の家鷄の姿勢を比較した.

圣，阷極右耳，陽極左耳の場合も，陰極: 左耳, 陽極右耳の場合它頭部, 頸部, 身匱

いそそれ以後遮電する迄，除極側仁頭部，頸部を僱倚さ せ，陰極側へ頭振を発来させる。

5 分間通䉓の後, 遮電すると, 家鹈の頭部, 頸部は通 電中より更に左側 (陰極側) 一約90度偏倚させる。この 時電気刺㦸当初の家鷄に見られた如き翼を括げ，止り各 上に辛らじて止る姿勢の失調はないここの姿勢さり右側 （陽桴側）に向与電流性後頭振を活発に発来させる，遮 電後 5 秒にて頭部, 頸部は㓌㥛側入約 60 度偏倚 $\mathrm{L}, 10$ 秒儿て陰極側入約 30 度となり，18秒にて正頭位へ杘り， 頭振 13 打を数えた。

4〜4,5mA, 8〜10V の電気剌战は家鴭にとつては異常 な強刺䇝であり，剌晖当初の家粕はこの通電，遮電時の

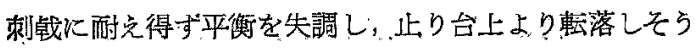
になり，篹を搪げて辛うじて止り台上にいる。しかるに
幹の偏倚方向, 頭振の方向が逆になるのみで, 電気刺, 㦸に効して同様の姿勢の変化を表わすので, 隆極右耳， 陽極左耳の場合のみ述へる。

隍極右耳，陽極左耳に 置いた電気刺战初回の 家鵎の 姿勢と，反覆電気刺战を筫荷した第 14 日目のNo. 1 白 色レダホンの姿勢とを比較して見ると，第 10 図，第 111 図，第12図，第13図の如くである，第10図は向つて 左側が 反覆電気剌战第 14 日目の家䳕 (No.1 白色レグ ホン）で，向つて在側が震気刺战初回の家稳で，各々通 電開始直後の姿勢である，雙方共，頭部，頸部は左側n 即ら陽極側に偏倚している。

しかるに留気刺战第 14 日目の家鴭には，転制せんと: して翼を搪げ，辛うじて止り台上に止る平衡失調は見ら

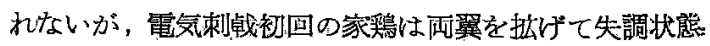


にある、第 11 図は電気刺㦸第 14 日目の家鴭（间つて左

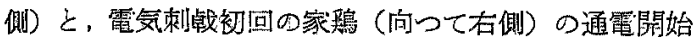

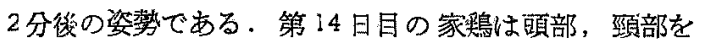

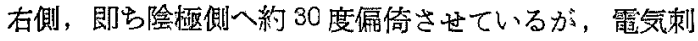
战初回の家鷄は頭部，頸部を左側，即ち陽梌側へ約 60 度偏倚させている，両者の䫏部，頸部の偏倚与问は全く 逆になつている.この時而者住共除極側入间ら頭振を 発来中である、第 12 図は笔気刺战第 14 日目の家鷄（何 つて左側）と，電気剌战初回の家鷄（向つて右側）の遮 電 2 秒後の姿勢である。第 14 日目の家鷄は頭部，頸部 を通電中上り更に右側，即ち陰極側へ約 40 度俏倚させ， 姿勢の失調は見られない，雷気束㦸初回の家鴭の頭部， 頸部は通電中左側（陽極側）に㾫㥓していたが，逆に右 側 (隍柾側) に強く約90度倔倚させ，二瞬翼を拡げて姿 勢の失謂をきたし，止り台上より檕落せんとするのを危

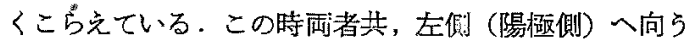
電流性後頭振を発来している，第 13 图は遮電1 分後の

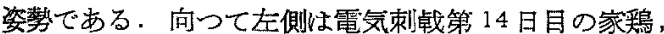
向つて右側は電気刺战初回の家焉である。第 14 日目の 家鵎は陽極側入向与電流性後頭振を全く終了し, 頭部, 頸部，躲幹は中央へと戾り，更に頭部，頸部はこれをこ 艺て左側 (陽梪側) に約10 度偏倚した位置に止つてい る.電気刺㦸初回の家鵎は頭部，项部，身區幹を右側（陰 亟側） 一強く約 70 度偏倚させ，左側 (陽極側) 一间与電 流性後頭振をな和盛ん化発来中である。

第 2 項 反覆電気刺㦸による家鷄の通電中， 遮電後の頭振

反覆電気刺戟により家鵎の姿勢は 以上の如く変化す る. 通電中は電流性頭振, 遮電後は電流性後頭振を発来 するが，この变化の模様を次ぎに述べる，頭振発来型 式, 頭振の変化の模様は, No. 1, No. 2, No.3 白色レグ ホン其に原則的に同様の傾向を表わしたので，No. 1 白 色レグホンについて，その詳細を述べ，No. 2 No. 3 白 色レグホンは第9表にある如く，電気刺㦸初回，第7日 目，第 14 口目の頭振の変化についてのみ述べる。

A. 通電中の頭振の变動

頭振は通䇩開始と共に陰極側に向つて発来し，通電中 持統守る。遮笔と同時に陽極側に向ら頭振，即ら䉓㳢性 後頭振を発来する。この通電中に発来する頭振の反覆通 婯14日間の変動について述べる。

第4表は No. 1 白色レダホンに.4〜 4.5mA，8〜10V の平流を 5 分間通敏した時の，5分間に打つ頭振数の变 動を表わしたものである。即ら通電第1日目の頭振数

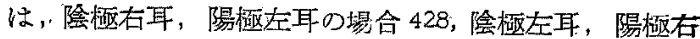

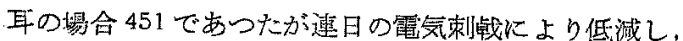
通電第7日目に陰栖右耳，陽極左耳の場合 192，陰極 左耳，陽極右耳の場合 200 を数克，約半数以下に激減し ている、しかるにその衡は減少を示さず，通篦第14日 目には陰極右耳，陽極左耳の場合 199，隍梅左耳，陽極 右耳の場合 195 である。

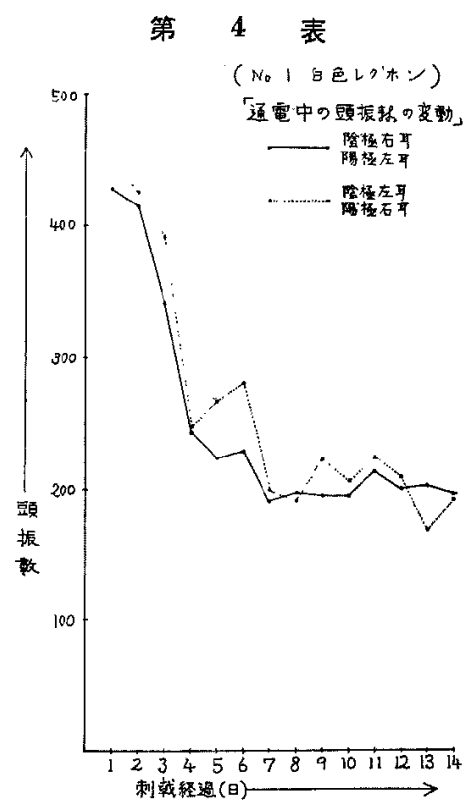

No. 2, No. 3 白色レグホンもほ 同様な 通䉓中の頭 振の減少をきたす

No. 2 白色レダホンに 4〜 4.5mA, 8〜 10 伻流を 5 分間通電した特の，5分間に打つ頭振数は次の如きで ある，通電第 1 日目の頭振数は，除極右耳，陽極左耳の 場合 501，陰極左耳，陽極右耳の場合 491 であるが連日 の電気刺战により低減し，通電第7日目には陰極右耳， 晹極左耳の場合 297，陰極左耳，陽極右耳の場合 349 を 数え，約 $3 / 5$ に減少している。

しかるにその後は著しい減少を示さず，通電第14日 目に心陰極右耳，陽極左耳の場合 262, 陰極左耳，陽極: 右耳の場合 294 である。

No. 3 白色レダホンに 4〜4.5mA, 8〜 10V の平流を 5 分間通笔した時の，5 分間に打的頭振数は次の如きて ある，通電第 1 日目の頭振数は，陰極右耳，陽極左耳の 場合 314, 陰極左耳，陽極右耳の場合 304 であるが連日 の電気刺钱により低減省るが，No. 1，No. 2 白色レグ 
:水ンより低減しない 即ち通電第 7 日目は陰極右耳, 陽 極左耳の湯合 248, 陰極左耳, 陽㥛右耳の場合 259 であ る。通電第 14 日目は陰極右耳，隄極左耳の場合 236，陰 㥛左耳，陽極右耳の場合 213 を数え著しい減少を示さな W.

通電開始時と通電中の頭振の打数を検するため 10 秒 毎の頭振数を計測し，表にして見た。第 5 表は電気刺钱 当初, 電気剌战第 7 日目, 麗気刺戥第 14 日目の No. 1 白色レダホンに招ける通電中の10 秒每の頭振数の変動 を表わしたるのである。即ち通電開始時には打数が著し く多く，始めの10 秒間がそれ以後の10 秒間の頭振数の 約 2 倍である。始めの10 秒間を除く通電 5 分間の 10 秒 毎の頭振数は大美なく平均して発来している，又，7日 目之14 日目の打数は殆んど差異がない，只 2 分以後に ては14日目の打数は少い傾向を認める.

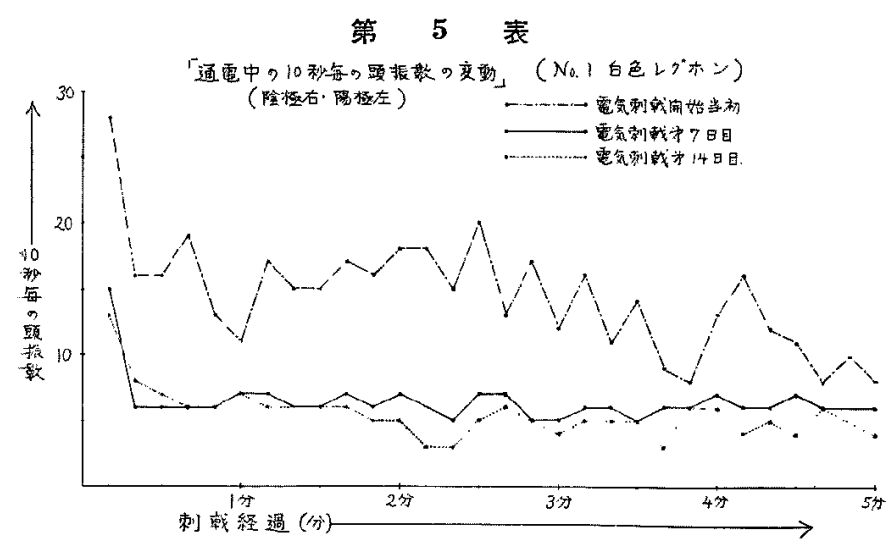

No. 2, No. 3 白色レグホンわ No. 1 と同様に, 通電 開始の頭振数が著しく多く，始めの10秒間がそれ以後 の 10 秒間の頭振数の約 2 倍である.

B. 電流性後頭振の変動

遮電と同時に，通電中陰極側に向つて発来していた頭 振は方向を变え, 陽極側に向う電流性後頭振を発する，

この電流性後頭振の反覆通電 14 日間に打ける变動につ いて述べる.

第6表，第7攱はNo. 1 白色レグホンに 4 4.5mA， 8〜10V の平流を 5 分間通電して遮電した時の電流性後 頭振持絸時間及び電流性後頭振数の变動を表わしたもの である，通電第1日目の電流性後頭振は，陰極右耳，陽 極左耳の場合，持緢時間 132 秒，後頭振数 83 , 陰極左 耳. 陽極右耳の揚合，持続時間 143 秒，後頭振数 87 で 西るが，通電 7 日目の震流性後頭振は，陰極右耳，陽極
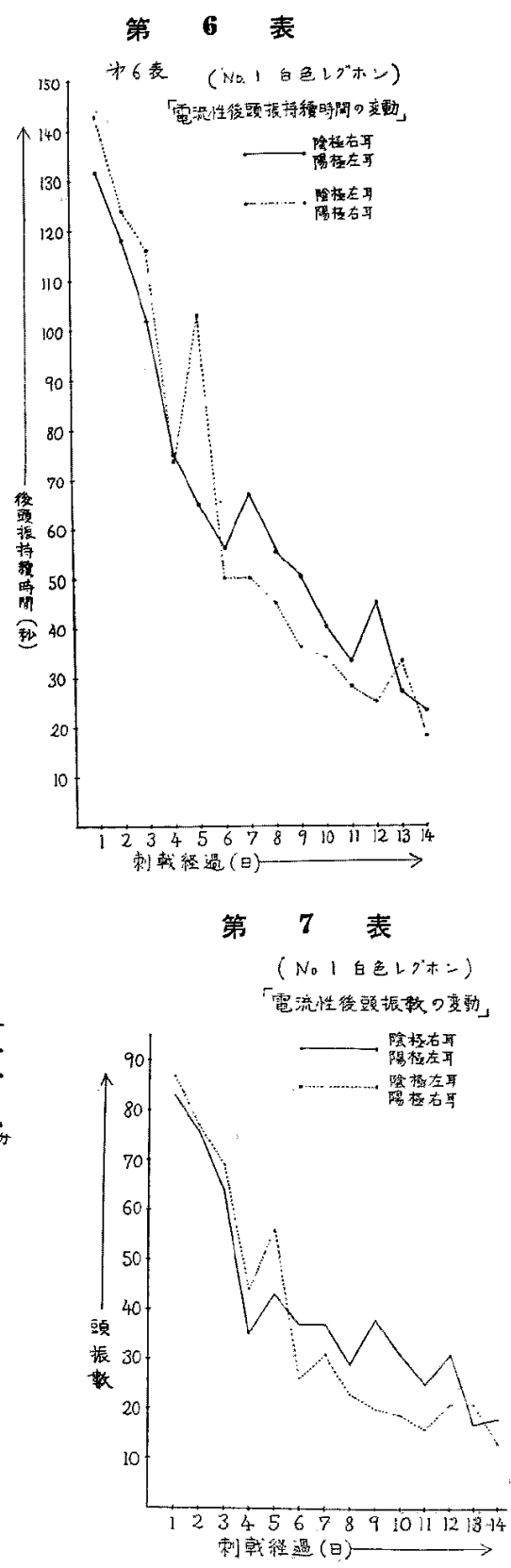

左耳の埸合，持綕時間 67 秒，後頭振数 37 ，陰極左耳， 陽極右耳の場合，持俧時間 50 秒，後頭振数 31 である。 通電第 14 日目には陰極右耳，陽㭴左耳の場合，持続時 間 23 秒，後頭振数 18 , 陰極左耳，陽極右耳の場合，持

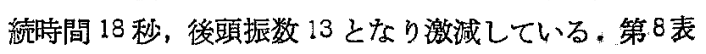
は No.1白色レグホンに括活る㓌拯右耳, 陽極左耳の 


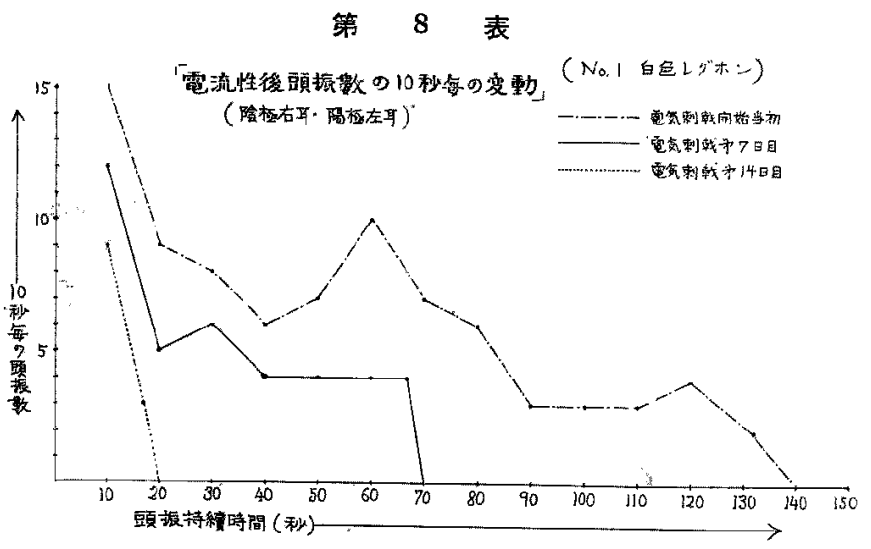

19 秒，打数 24 で方る．即セ持繶時間，打 数とも 14 日目に淿約 $1 / 4$ 以下に低滅して いる.これも通電中の頭振が低娍するる， 7 日目と14日目に执いては殆んど差異な。 きことつ，著しい対照を示す。

No. 3 白色レダホン 4 4.5mA, 8〜10 V の平流を 5 分間通電して遮電した時の電流: 性後頭振の持続時間及び頭振数は次の如く である。

通電第 1 日目は陰極右耳, 陽極左耳の場 合, 持繶時間 86 秒, 打数 57 , 陰梂左耳, 陽極右耳の夠合，持䋨時間 85 秒，打数 56
場合の電流性後頭症数の 10 秒每の変動を表わしたもの である。即ち電流性後頭振は反覆電気刺战にて著しく但 減し，持続時間，打数とも 7 日目には約 $1 / 3$ 亿減じ，14 日目には約 $1 / 7$ 亿低隇する。これは通電中の頭振が低減 するる7日目と14日目に执いては殆んど 差異なきこと と、著しい対照を示す. No. 2, No. 3 白色レグホンも 同様に電流性後頭振の著しい低隇を見たが以下の数值を 第9表に掲げ述べる。

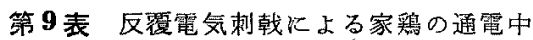
㵂電後の頭振の消長

\begin{tabular}{|c|c|c|c|c|c|c|c|c|c|c|}
\hline \multirow{3}{*}{ 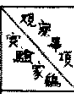 } & \multirow{3}{*}{\begin{tabular}{|l} 
笛極 \\
部 位
\end{tabular}} & \multicolumn{3}{|c|}{ 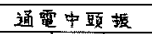 } & \multicolumn{6}{|c|}{ 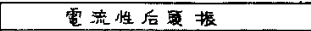 } \\
\hline & & \multirow{2}{*}{ 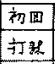 } & \multirow{2}{*}{ 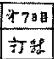 } & \multirow{2}{*}{\begin{tabular}{|l|}
71938 \\
7592
\end{tabular}} & \multicolumn{2}{|c|}{ 初 } & \multicolumn{2}{|c|}{478} & \multicolumn{2}{|c|}{ H 14 日目 } \\
\hline & & & & & 然政 & 打玒 & $\mid$ & 打将 & 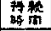 & 办以 \\
\hline \multirow{2}{*}{ 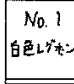 } & 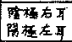 & 428 & 192 & 199 & 132 & 83 & $67^{\prime \prime}$ & 37 & $23^{\prime \prime}$ & 18 \\
\hline & 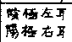 & 451 & 200 & 195 & $143^{\prime \prime}$ & 87 & $50^{\circ}$ & 31 & $18^{\prime \prime}$ & 13 \\
\hline \multirow{2}{*}{$\begin{array}{c}\text { No. } 2 \\
\text { Ge.t. }\end{array}$} & 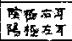 & 501 & 297 & 262 & $107^{\prime \prime}$ & 72 & $8^{\prime \prime}$ & 44 & $21^{\prime \prime}$ & 23 \\
\hline & 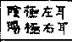 & 491 & 349 & 294 & $95^{\circ}$ & 65 & $40^{\prime \prime}$ & 34 & $19^{\prime \prime}$ & 24 \\
\hline \multirow{2}{*}{ 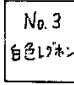 } & & 314 & 248 & 236 & $86^{\prime \prime}$ & 57 & $43^{\prime \prime}$ & 39 & $21^{\prime \prime}$ & 19 \\
\hline & 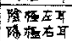 & 304 & 259 & 213 & $85^{\circ}$ & 56 & $42^{\prime \prime}$ & 33 & $22^{\circ}$ & 20 \\
\hline
\end{tabular}

No. 2 白色レグホンに 4 4.5mA, 8 10V の平流を 5 分間通電して遮電した時の電流性後頭振の持続時間及 び頭振数は次の如くである。.

通電第 1 日目は陰極右耳，陽極左耳の場合，持緮時間 107 秒, 打数 72 , 院極左耳, 陽極右耳の場合，持続時間 95 秒, 打数 65 である. 通電第 7 日目は陰極右耳, 陽極 左耳の場合，持緮時間 38 秒, 打数 44 , 陰極左耳, 陽極 右耳の場合，持続時間 40 杪，打数 34 である. 即ち，持 続時間，打数之も 7 日目には約 $1 / 2$ 亿低減している。通 電第 14 日目飞は陰極右耳, 陽極庄耳D場合，持綕時間 21 秒, 打数 23 , 陰極左耳, 陽極右耳の場合，持続時間
である。通電第7日目は陰極右耳，陽㥛左耳の場合，持 䋉時間 43 秒, 打数 39 , 陰極左耳, 隄極右耳の場合, 持 綕時間 42 秒, 打数 33 である. 即ち持続時間, 打数とも 7 日目に治約 $1 / 2$ 亿低減している，通電第 14 日目には 陰極右耳, 陽極左耳の場合，持続時間 21 秒，打数 19 , 陰極左耳, 陽極右耳の場合，持続時間 22 秒，打数 20 で ある. 即ち持続時間, 打数之も 14 日目《は約 $1 / 4$ 以下 に低減している，通電中の頭振が渚明に低減しないのと 対照的である。

第 3 項 反覆電気刺战を課した家鵄の迴転刺战 に対する反射の变化

以上の如く連日反覆電気刺战を負荷し，通電中の頭振 及び電流性後頭振の低減をきたし，かつ通電中電流々反 対方向に偏倚していた頭部, 頸部が電流と同方向に偏倚 するようになつた家鵎，即ち通電第 14 日目の家鴭の迴。 転刺㦸に対する反射の变化を検討した，即ち迴転椅子の

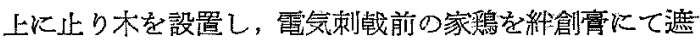

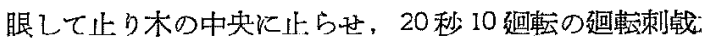
を負荷し，去の迴転中及び廻転後の姿勢並びに廻転性後 頭振を検し，この家鷭に反覆電気刺瑝を 14 日間負荷し た後，同じく回転刺㦸を課し，両者につき䢐転中及び迴: 転後の姿勢，並びに迴転性後頭振とを比較検訫した。

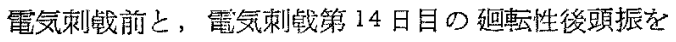
第10表に表わした。

第 10 表の如く, No. 1, No. 2, No. 3 白色レがホン

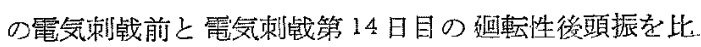
较すると，第1相，第 2 相任々の持続時間，打数ともに 約 $1 / 2$ 以下に低減している。

次に新たに電気刺戟を14日間課した家䲮と, 正常無 処置の家殦を遮眼し，共に迴転椅子上の止り木に並心 て乗せ， 20 秒 10 迴転の迴軾刺战を負荷し，その耐者の 


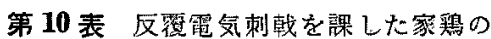
超呍性後㖽振の消長

\begin{tabular}{|c|c|c|c|c|c|c|}
\hline \multirow{2}{*}{ 实窟 } & \multirow[b]{2}{*}{ 起㩆方向 } & \multicolumn{2}{|c|}{ 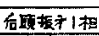 } & \multirow{2}{*}{ 休上期 } & \multicolumn{2}{|c|}{ 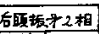 } \\
\hline & & 㛢 & TTH & & 型得 & 方壮 \\
\hline \multirow{2}{*}{ 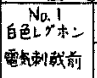 } & 右邀䟲 & 17 & 23 & $4^{*}$ & $12^{\circ}$ & 10 \\
\hline & 支题标 & $18^{\prime \prime}$ & 27 & $5^{\circ}$ & $10^{\prime \prime}$ & 9 \\
\hline \multirow{2}{*}{ 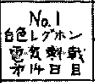 } & 右栦枟 & $8^{\prime \prime}$ & 12 & $3^{\prime \prime}$ & $4^{4}$ & 2 \\
\hline & 左越知 & $8^{\prime}$ & 11 & $3^{n}$ & $4^{\prime \prime}$ & 3 \\
\hline \multirow{2}{*}{ 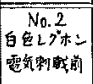 } & 右通星 & $19^{\prime \prime}$ & 20 & $4^{\circ}$ & $12^{\prime \prime}$ & 8 \\
\hline & 左程梳 & $20^{\circ}$ & 23 & $3^{\circ}$ & $11^{n}$ & 7 \\
\hline \multirow{2}{*}{ 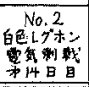 } & 右迎䖝 & $8^{\prime \prime}$ & 12 & $3^{\prime}$ & $4^{\prime \prime}$ & 2 \\
\hline & 左和索 & $7^{\circ}$ & 9 & $3^{\prime \prime}$ & $3^{\prime \prime}$ & 2 \\
\hline \multirow{2}{*}{ 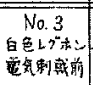 } & 右遇車 & $20^{\prime \prime}$ & 19 & $4^{4}$ & $12^{\prime \prime}$ & 7 \\
\hline & 左超転 & $19^{2}$ & 21 & $5^{4}$ & $10^{*}$ & 7 \\
\hline \multirow{2}{*}{ 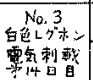 } & 右造枟 & $7^{\prime}$ & 8 & $4^{\prime \prime}$ & $3^{\circ}$ & 2 \\
\hline & 左建船 & $7^{*}$ & 7 & $3^{4}$ & $1^{\prime \prime}$ & 1 \\
\hline
\end{tabular}

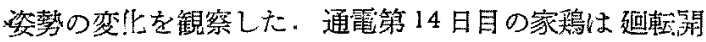
始と共心迴転と逆方向に頭部，頸部を一時虑倚させる が，第 14 図に見られる如く，10秒後には頭部頸部を䢙 転之同方向へ偏倚させ，以後迥跬中恒にこり万向に頭位

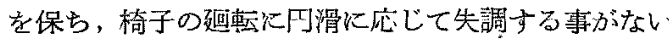

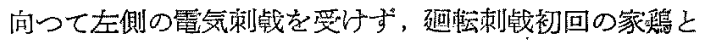
は対称的な姿勢である，迴転停止と共第 15 図に見ら える如く，通電第 14 日目の家鵄は頭部，頸部を椅子の

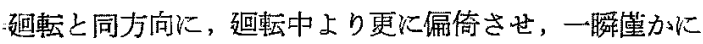
翼を㹡げるが，姿勢は崩れず強い平衡失調は見られな い. 向つて左側の䉓気刺㦸を受けず, 迴転刺战初回の家 鵎は，椅子の迴転を停止すると呬転中，迴転之逆方向に 偏倚していた頭部，頸部は，中央をこえて逆に椅子の迴

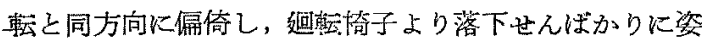
勢が崩れ，翼をバタつが，辛らして止り木上に止る姿 勢の失調をきたす。っいで迴軽:亭止 10 秒後の雨者の姿 勢を比転して見ると，第 16 図の如く向つて右側の通籍

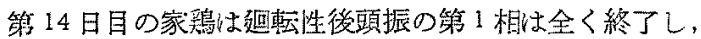
頭部，頸部は中央へ尤り，更に中央をこ克て迴転と逆方 向へ約 30 度偏倚して止っている．乙かるに向かって左

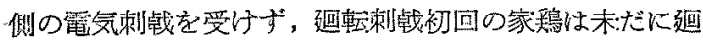

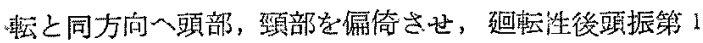

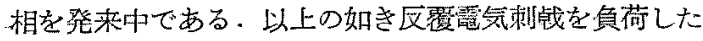

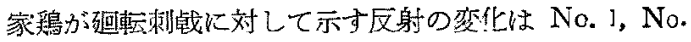
2, No. 3 白色レグホン共化類似の成績を示した.

\section{第 2 章 総 括}

遮眼し視覚の介入をさけ，止り木上に止らせた家辑の 両側耳部汇連日 4 4.5mA，8～10V の平流を5 分間，
10 分間の間隔を置いて，極性変换をして 5 分間，計 10 分間急荷し， 14 日間課した。 その結果; 電気刺钱開始 当初上第 14 日目の家鵄に叔りる通電中及び遮䉓後の家 舀の姿勢，頭振の持続時間並びに打数に著るしい差異を 認めた，又，反覆電気刺战が迴転刺㦸に及ぼす影響を観 察せえがために，電気刺战前と，連日反覆電気刺战第 14 日目の家鴊の Bárány rotation に和りる迴転中，迴 転後の姿㙯，及び迴転性後頭振を検討するに車者に著る しい差異を認めた。即ち電気刺战を14 日間課した家舀 は電気刺踤前の家鶏に比べて，電流開閉時の刺㦸に対し 淩起される失調に影をひそめ，止り木上の姿勢の維持が

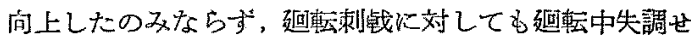
ず，後頭振を著しく低減せしめ得た，以上を要約すれば 次の如くである。

1）家鶏を遮眼し止り台上に何等束䌗を 加える事なく とまらせ，耐側耳部に同大（厚さ $0.2 \mathrm{~mm}$, 直径 $18 \mathrm{~mm}$ ) の電極を固定し，4４.5mA，8～10V の平流を負荷す

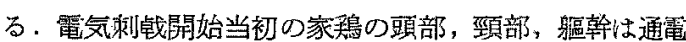
と同時值ちに陽極側に著しく偏倚し，止り台上方解落 せんばかりに平衡は失調し，2〜3秒翼をバロつかせ活 翼を抎げて辛うじて止り台上にあり，通電中この惼倚姿 勢をとり，陰極側に问から頭振を盛儿に発来する。

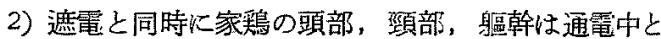
は逆方向の陰極側に偏倚し，2〜3秒翼をバタつが，

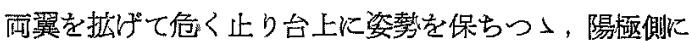
向から電流性後頭振を盛九に発来する。

3）しかるに連日通電を反覆した第 14 日目の家熎は，

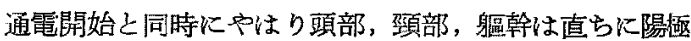
側（䉓流と反対方向）に偏倚するが，約 10 秒にて漸次陰 極側に頭部，頸部は向かい，正中位に達し，次いでこれ をこ克て除極側（電流と同方向）に偏倚し，通電中この

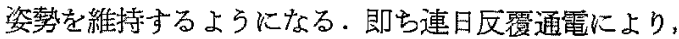
通電中の家鵎の頭部の偏倚方向は全く逆方向となる。な 标，電気刺战開始当初の家鷄は通電開始時及び遮電時の 刺㦸によりて，通電開始時は陽極側に，遮電時は陰極側 に額落せてばかりとなり，両翼を拡げ，バタつかせて姿

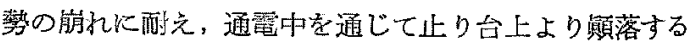
のを份くこらえている，しかるに連日通髣が反覆される

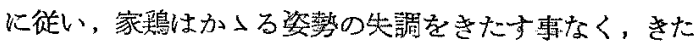
しても瞬持にして近直る。

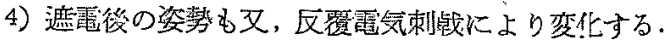
電気刺㦸開始当初は尷電已同持涻極側一頭部, 頸部, 身畐幹老偏倚させ，陽㥛側火向から電流性後頍振を発来す 
る.陰極側へ偏倚した家留の頭部, 頸部, 身區幹が正中位 飞古直るのに要する時間は約 100 秒である。しかる運

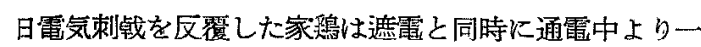
㬝陰極側へ頭部，頸部を偏倚させ，陽極側に向与電流性 後頭振を発来するが，約 20 秒にして正中位に正直る。

5）通電中の頭振は通電 5 日乃至 7 日迄は 反覆電気测 践にで半減する. しかしそれ以上反覆電気刺战を課して 妇低減は見られない。

6) 電流性後頭振の低減は著しい，即ち持続時間，打 数上も反覆電気刺战 7 日目には約 $1 / 2$ 亿，10日目には 約 $1 / 4$ 亿減ずる、なお，迴転，温度刺战で䚄々覾察され る第 2 相は反覆刺战前も，刺㦸後も本電気刺战实験では 認めなかつた。

7) 電気刺战を全く負荷しない家鵎と，反覆電気刺战 を負荷し，通電中の頭振及び電洗性後頭振の低減をきた し, か心通電中家鷄の頭部, 頸部が除栖側, 即々笔滋 と同方向に偏倚するようになつた第14日目の家鷄の Bárány rotation に拈ける成績㵔しい差翼を示す

a）電気刺战を負荷する前の家舀の迴転性後頭振上， 反覆電気刺战真荷した家鵃の迴転性後頭振とを比べる と，後者に执いては第 1 柏も第 2 相も共厄著明低減し ている.

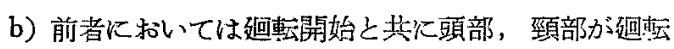
々逆の方向に偏倚し，椅子の画㲦中その资攀を維持して いるが，後者も同じく迴転当初は頭部，頸部を迴轻と逆

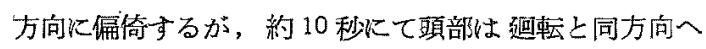

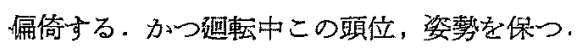

c）前者は迴転中も，迴転停止後も，止り木に止つた 姿攀を保ち難く，しばしば顛落しそらになり，両翼をバ タつかせ挀げて危く止り木上に止るが，後者は円滑に迴 転に対しその姿勢を維持するに到り，失調はなく，あつ て子瞬時沉て立直る。

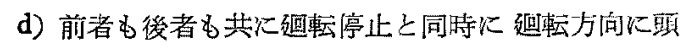

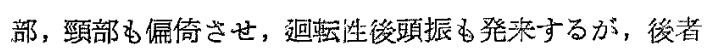
の後頭振の 持:続時間並びに打数は前者の $1 / 2$ 以下にし て，上り早く頭部を正中位に戾した正常姿攀にかえる，

\section{第 3 章 考按}

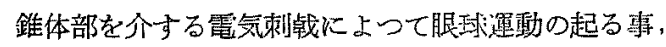
瞱最の起る事は既に古くPurkinje ${ }^{12)}$ (1820 年) が観察 している. その後 Hitzig, Kny, Breuer ${ }^{11}$ 等は (1) 露

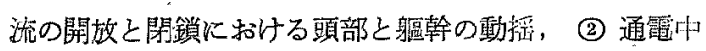
のニスタグムス栐腿球運動の出現を報告し, Hitzig と Knyはこの運動を小腷の刺钱による結果とした。しか
ᄂ Breuer は両側迷路除去後は頭運動が起ら奴と云5 Ewald の害験を根拋として，前庭の刺㦸によるもので あろらと主張した. 更に Bárány ${ }^{11)}$ は一側の Bogengang を破㙥すると,その耳側に Nystagmus を発来 せず，两側破罱後は電気反応を起さないことを示した。 しかるにその後 Neumann, Ruttin, Marx 11) 等は完 全に破壊された迷路に执いて子な括，電気性眼振の発来 する事を实恠した，Mackenzie 11) はこれら反対意見の 仲介を成する头蹒を示した，即ち，迷路が破壊される と，普通，眼振を発来させるに充分な電流の強さでは眼 振を発来しないが，それより一賣電流を強めると，反応 を現す事を見出した，以来通電による腿，頭の Nystagmus は第 8 神縃幹が刺战されるためであると考学られ ている，最近に至つて Dohlmann 13)14) は電気的迷路 反応は前庭神経節から由来するものであること説き，

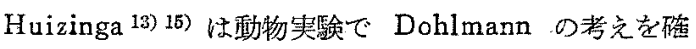
定する事はできなかつたと述べている，かくの如く電気 就戱における反射発現部位については稙々の考察があ 3.

刺战条件とか反射発現㥞式について小田 ${ }^{16)}$ 17) 18) は両 側耳間の刺战部位に执いて海猽，家禹及び猫を用いて観 察し，通電中眼振が隍梗側に占い，遮電直後には眼振の 方向を変換する. 又, 頭偏倚は 3〜4mA で始まり，つ いて眼振は 6 8 $\mathrm{mA}$ で発来すると述べ, Huizinga ${ }^{19)}$ は鳵では 0.04〜0.1mA で頭偏倚を， 0.1〜0.2mA で眼 振を認めると報告している。石原 20)21) は家臣では 0.05 〜 $0.1 \mathrm{~mA}$ で頭偏位を， $0.5 \sim 2 \mathrm{~mA}$ で腿振を譛め，小幡

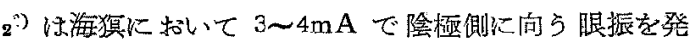
現し，隍極側は $1 \sim 6 \mathrm{~mA}$ で上方へ向う眼偏位を，陽極 側は 3〜9mA で下万へ向う眼偏位を認好てい。，石川

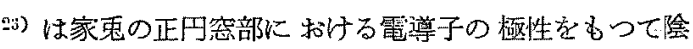
極通電，刺㦸，あるいは陽梗通電刺战として通電する

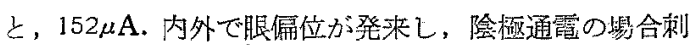
㦸側の腿は前上万に，陽極通電で刺戟側の眼は後上方に 偏位するの哂訦たと報告している。

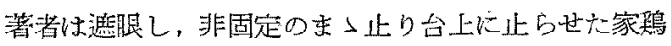

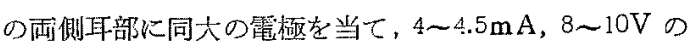
通電量にて発玧する頭振，及び㽬部，巠部，身翰の偏倚

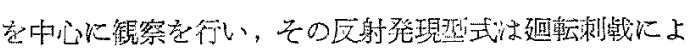

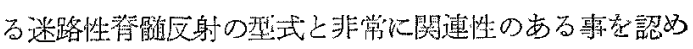

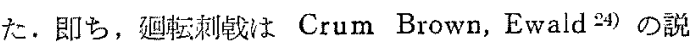
の如く，一方向への迴転刺钱が与光られた場合，両側の 迷路が同じょうにこの迴忶测战を受容し反射を発現する 
のではなく，右䢙転に効しては主として有の迷路が，左 迴転に対しては主として左の迷路が迴轻剌㦸を受容して

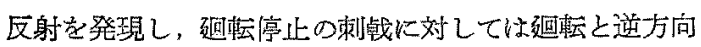
の迷路が剩戰を受容し，反射を発現すると云ら反身型式 である、これに刘し，上く似た反射を星する電流による 迷路反射発現の機序については Marx 25) 及び小国 ${ }^{16)}$ 17) 18）等も報告している如く，Pflüger 26) 27) 28) 29) の䉓

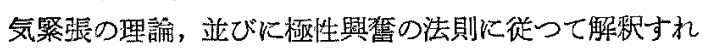
ば次の如くである. 即ち，家鵎の石耳に隆極を，左耳に 陽極を゙当て通電すれてば，通電開始にて頭部，頸部，軀幹 は左側 (陽㥛側) に僱倚し，右側（陰極側）に向亏頭振

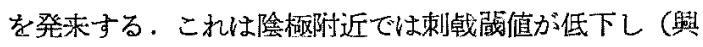

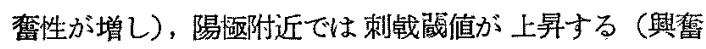
性が減る）之云う電気緊張の理猃から，除極側，即ち右 の迷路が主として束㦸される結果起る迷路反射と解すれ ば，右迴転刺战の場合上関連性のある事が推察される。

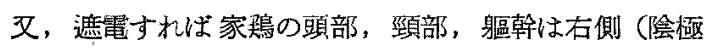
側) に偏倚し, 左側 (陽㥛側) に向与頭振を発来する. 即らこれる通電時には陰梅下，遮電時には陽極下にて與

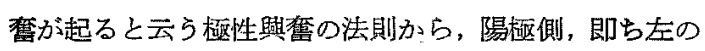

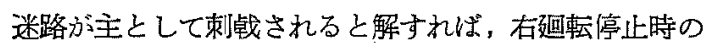
刺践との関連が推察される。つまり画極刺战にて院極を 右耳にすれば右䢙転，陰極を左耳にすれば左迴転に柏当 すると推察できる．電気性迷路刺战と他の迷路刺㦸との 関保について，既に M.H. Fischer 18) 及び Hitzig ${ }^{13)}$ が電気を通じた場合にも，甶転や冷温刺战と全く同様な 前庭性身体反射を現す事を報告し，しか子温度性刺战に ついて陽極は冷洗淡側に，陰極は温洗涤側に柜当すると 云ら事を観察している。

本实験は緒言に掲げた目的を以つて家鵚の頭部に連日 雷気刺㦸を反覆誯し，果して著るしく迷路反射の様相を 変化せしめ得たものである。この変化を次ぎの如く考察 寸る. 家鷄の頭部に 1 日量 4〜4.5mA, 8〜 $10 \mathrm{~V}$ の平流 にて栖性变換をして5分間ずつ，合計 10 分間の電気刺 㦸を連日貫荷する事により山現する迷路区射は，福田”

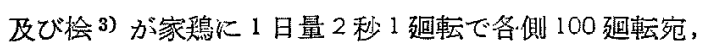
合計 200 迴転学連日負荷して钼察した迷路反射と奏に緊 密な関連ある事を認めた。即ち電気刺战開始当初の家禡 が通電中，電流之反対方向（晹極側）に頭部，頸部，躬

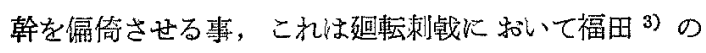
云う static labyrinthine reflex と等し?, 又, 連日 通電第 14 日目に観察される通電中，電流と同方向に䫒 部，頸部が偏倚する麗気刺㦸開始当初には全く見られな

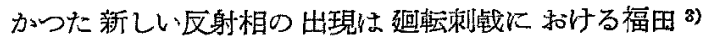
の云う kinetic labyrinthine refiex と同じ姿勢であ る。加連日電気刺㦸を賲荷する事に上り，連日迴転刺

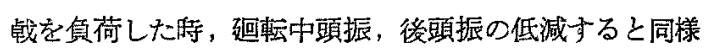
に, 通雷中頭振並びに遮留による後頭振の発来が著明に 低減した，更に注䉥すべきは，連日延転刺战を課すと， 廻転方向へ頭部，頸部支倨倚させる新しい反射相が出現

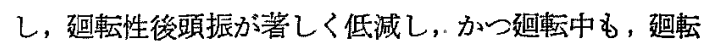
啳も翼をバタつがて危く止り木上にある姿樊の崩れは 影をひそめ，身体平衡が著しく向上する事が福田，桧3 により報告されているか゚，これと同様な事が電気刺㦸に おいても観察された. 即ち電気束戱を連日負荷する事に より, 通電約 10 秒にして電流と同方向に頭部, 頸部を 偏倚させる新しい反射相加出現し, 通電中の頭振の低減 並びに電流性後頭振の著るしい低隇をきたし且つ，通電 時及び遮電時に翼をバタつかせ止り台上さり顋落しそう になる姿勢の失調は認るられなくなる。

迴転刺战を連日動物に負荷すると低後眼振をさたす事 は古くからり数多くの実験により証明されている。し かるにその解积は，三半規管の現和す諸反心は強い刺战 が綶返克して与えられると減退して行くものであるとか 5), 迷路の疲労現象 ${ }^{8)}$, 順応之か損倁, 中枢作用 ${ }^{4)}$, 斯 れ6う)等, 色々の見解がある. 電気刺战に関しては神経 その他の與奮性形体を変化のゆるやかな電流で刺战する と，相当の強さになつても刺战とならず, 生体で電流に

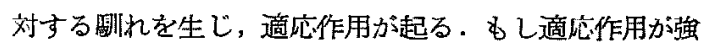
ければ時閏の経過と共に與奮性が減退するから反覆刺㦸 は無勃となり, 反覆與舊が起ら好事 即ら, 反覆與奮が 起るためには適応作用が少ない事が不可欠の条件である 事が知られている26)。石川 23) は家象の一側耳根部前下 方より中耳腔骨胞を開放し, 正円空部に飽和食塩水深 した小綿球を密に当て，大の部に銊众針，㕛は1/4 皮下 注射針を電導子として置き，他方の不関導子は中耳腔内

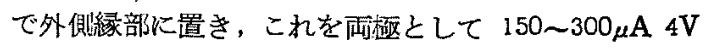
の直流にて陰極通電刺战を行うと, 家鬼の束此战側の眼は 前上方に偏位し，刺钱対側の眼は後下方に偏位し，頭部 は刺踥耳を上方にて刺㦸対側耳の方傾斜して頭偏位を きたし，脊柱は刺戟側を凹面として軽度に䇾曲し，前肢

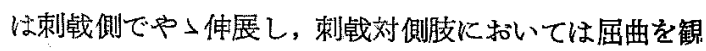
察している．更に石う门 ${ }^{23)}$ は陰極通電刺钱を反覆して結 返し行うと，前記の特異な家鬼の頭偏位が泩次孪化し， 遂には者明な頭㭊位を認めなくなつたと報告し，単独通 電刺践が反德されて加重される事により，次第に迷路に 


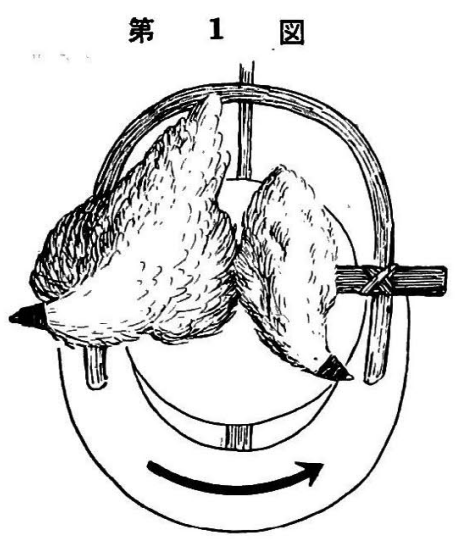

訓練家鷄（向つて右）未訓練家鵎（向つて左） 立迴転開始 16 秒の廻枟中の姿勢

$$
\text { 第 } 2 \text { 図 }
$$

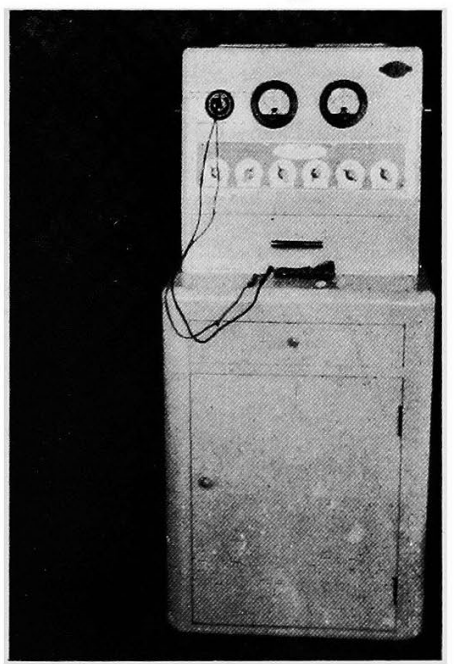

刺戟発生裝圆

第 3 図

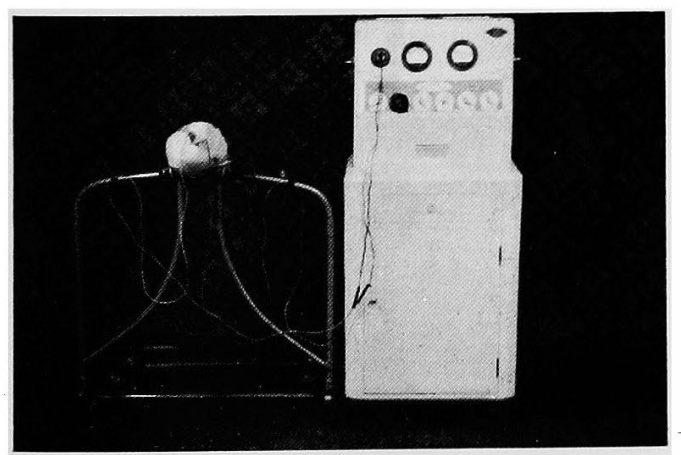

実 験 銥 固
第 4 図 電気刺戟開始当初の家貌

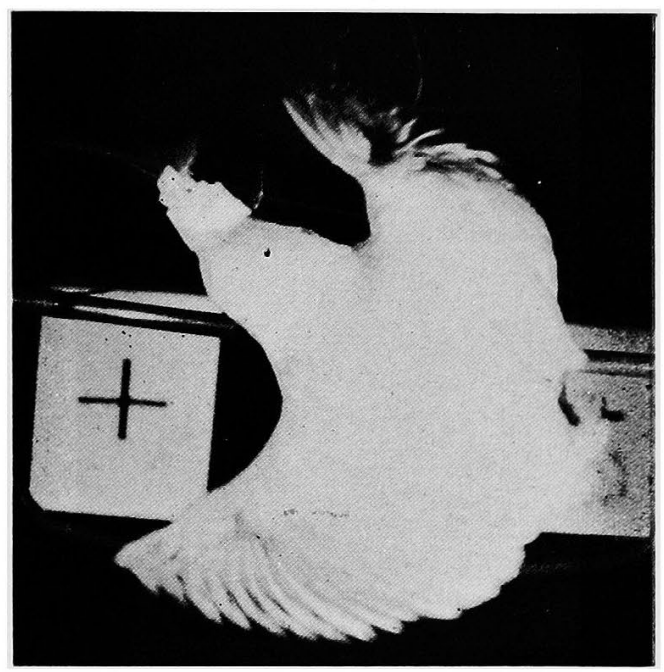

㓌極右耳：㟲極左耳通電開始 2 秒後の姿弯

第 5 図電気刺戟開始当初の家䳕

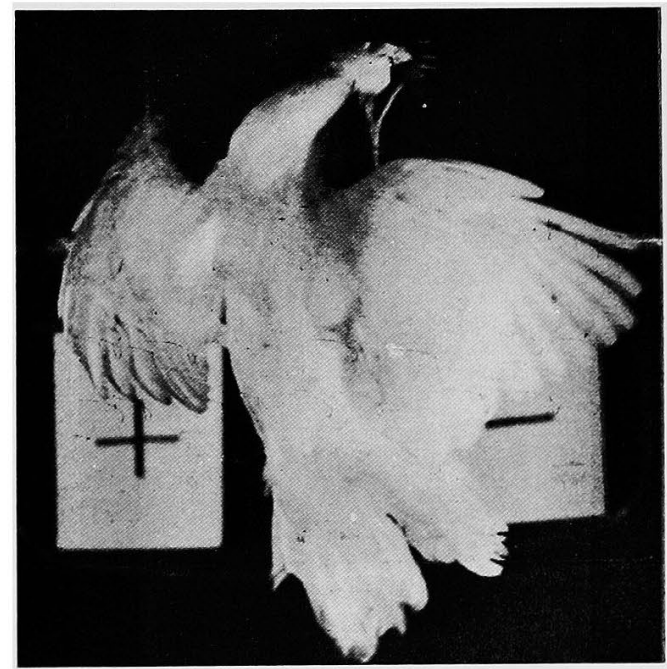

㓌極右耳：陽極左耳:㴧電直後の姿勢 
第 6 図電気刺幹第 14 日目の家鷄

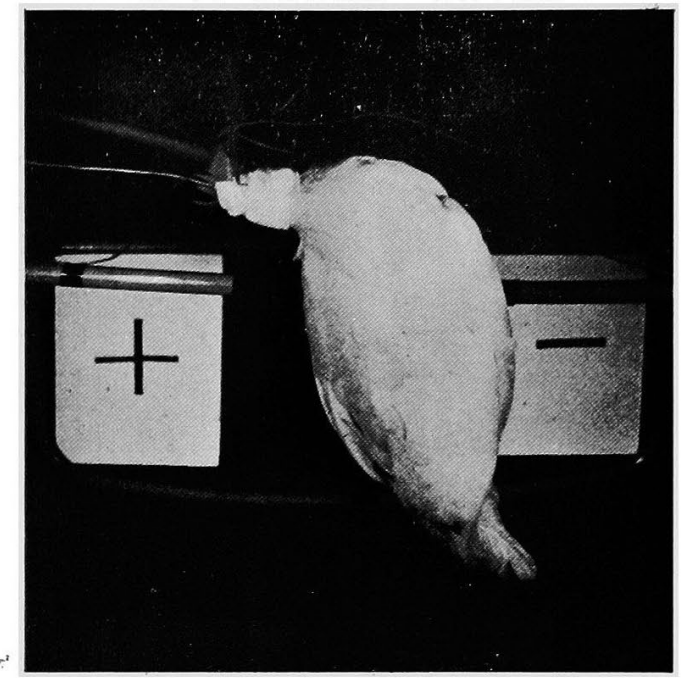

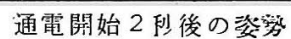

第 8 図電気刺戟第 14 日目の家鷂

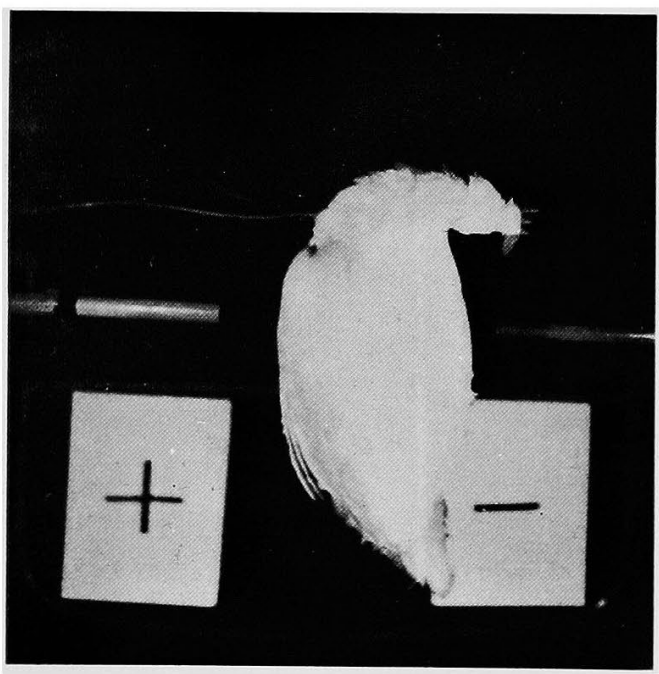

遮電直後の管勢

第 10 図

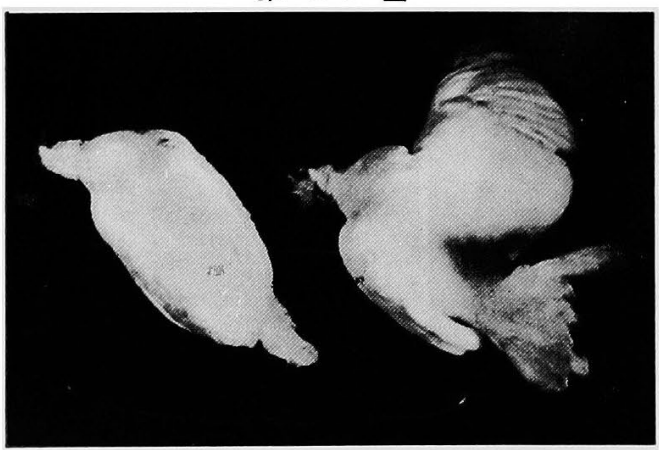

電気刺戟第14 日目の家鷄（向つて左） 電気刺戟初回の家鹈（向つて右）
第7図電気莿戟第 14 日目の家鶏

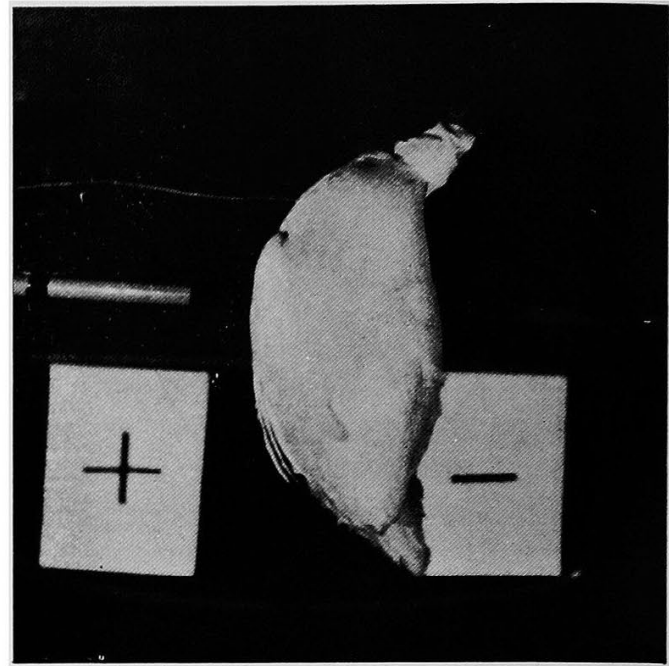

通電開始 2 分後の姿势

第9図電気刺戟第 14 日目の家鶏

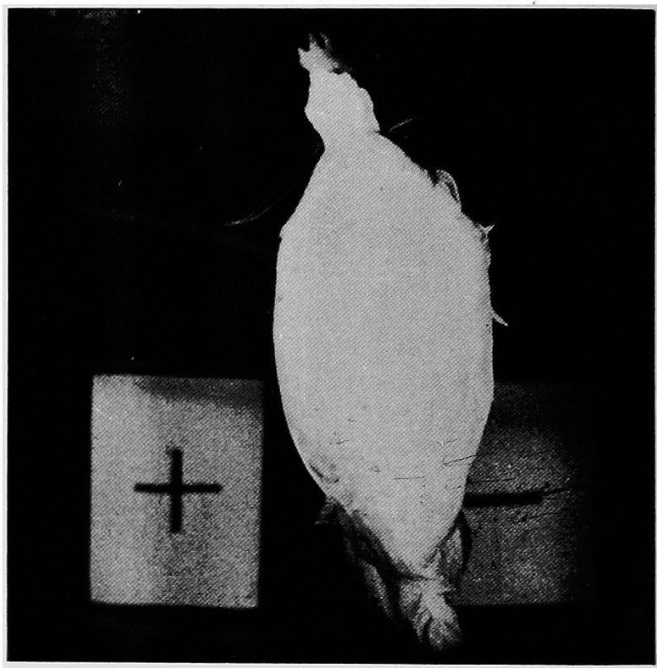

㶐電 1 分後

第 11 図

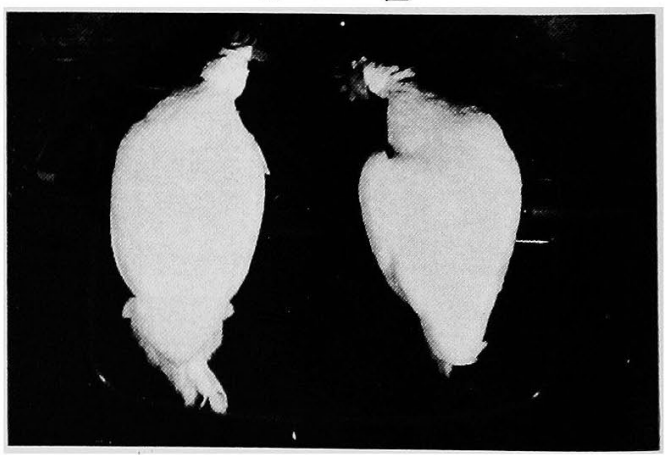

電気刺戟第 14 日目の家筜（向つて左） 電気刺戟初回の家鷄（向つて右） 
第 12 図

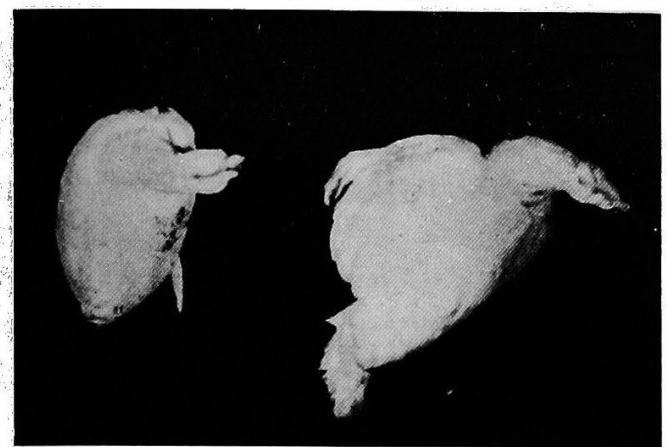

電気刺戟第 14 日目の家鷄（向つて左）

電気刺戟初回の家鶂（向つて右）

陰極右耳：陽極左耳遮電 2 秒後の姿勢

第 14 図

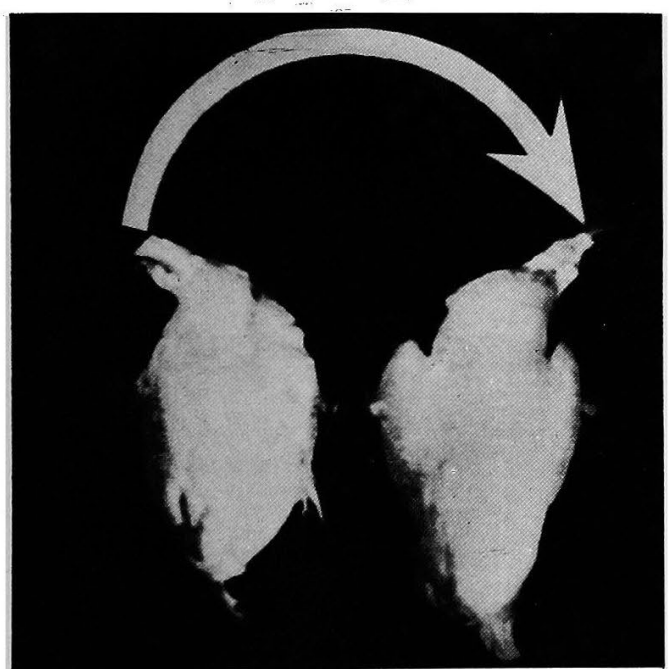

電気刺戟第 14 日目，趈枟刺戟初回の家熎. (向つて右) 電気刺戟を受げ，廻転刺戟初回の家鷄（向つて左）

趈転開始（嗨迴枟 20 秒 10 迴枟）10 秒後の姿勢 矢印は趣転方向を示寸

\section{第 16 図}

電気刺戟第 15 日目の廻転刺琝初回の家采: （向つて右）

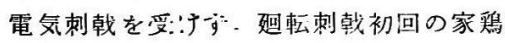
(向って左)

趈転停止（右趈枟 20 秒 10 奋枟）10 秒後 の姿繁
第 13 図

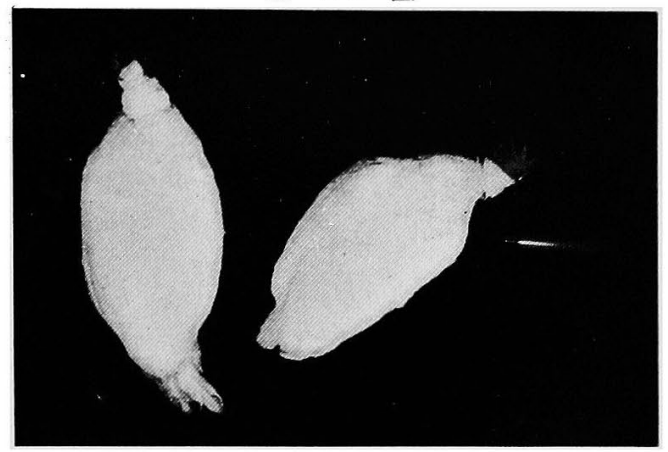

䉓気刺㦸第 14 日目の家繮（向つて左）

電気刺戟初回の家鷍（向つて右）

陰極右耳：陽極左耳遮電 1 分後の姿勢

第 15 図

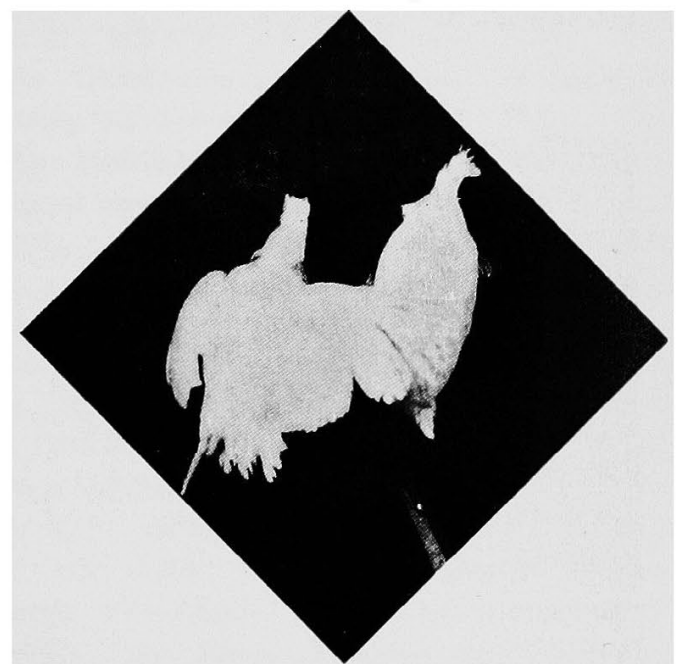

電気刺戟籁 14 日目，廻耺刺戟初回の家鶏（向つて右）

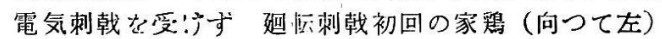

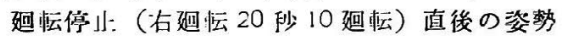


対する刺㦸間值が低下し，迷路は刺战による與禽が持続 している状態になつているるのと考察を加えている. し かし著者の行つた条件にて連日電気刺镉を負荷した家鷭 は，頭振の低減のみならず，止り木に家鷭を止らせるこ とにより頭部, 頸部, 身區幹に新しい偏倚, 新しい迷路反 射が形成され，回転刺㦸の連日加重に和いてみられた迷 路性平衡機能の向上と同一事実を証明し得た。故に廻転 刺战の訓練によつて得た向上と比蒣す心゙く，連日電気刺 战を課した第 14 日日の家鷂に迴刺㦸を始めて放えて 見た。その結果何んら刺战を与之ぬ正常無処置の家鵎に は全然なく，から連日反覆迴転刺战の家期の䝁樊にのみ 従来胃られていた廻転中，頭部，頸部が廻転方向八间 3., 福田 ${ }^{3)}$ の云ら kinetic labyrinthine reflex がこ の家鷄に出現し，か著明な迴転性低後頭振をきたし， 通電のみにて未た迴転刺战に遭つていないこの家鵎の迴

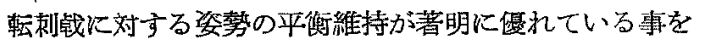
証し得たのは誠に第くべき事実である，故に著者は1日 量 4〜4.5mA，8〜 $10 \mathrm{~V}$ 極性变換をして各々 5 分ずつ，

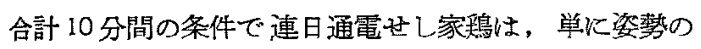
変化をきたし，頭振を低隇したと云うだけでなく，電気 刺㦸に対する失調状態がなくなり，平衡機能が著明に问 上した雪から，新しく現われた刺战が重なるにつれて， 新しい適灾加前庭迷路から構成され，更に高次の迷路反 射が成立したものと考光る。殊に連日迴転刺战の加重に より初めて得られた低後頭振及び新しく形成される高次 の迷路反射 kinetic labyrinthine reflex 即ち迴転中,

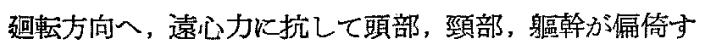
る延転に対する動的迷路反射が，廻転刺㦸でなく，頭部 通電刺战の加重により得られていた事を明らかにしたの は実跧者自身驚いた新しい事実で，今後の迷路生理学に 多大の示唆を供する成績と考える。

\section{主 要 文 献}

1) 星野：家㭸における前庭眼反射について並びに前庭 機能に対する知見補遗，北越医誌，4，37，2）湢田・ 檜: 訓練の生理, 運動之平衡の反射生理, 医学書院, 東京, 85, (1957). 3 3) Fukuda, Hinoki \& Tokita: Static \& kinetic labyrinthine reflex etc. Acta Otolaryng. $49: 467,(1958) .4$ 4) Halstead, Yacrozinsky \& Fearing: 120: 350, Amer. J. Physiol. 5) Dodge: J. Exp. Physiol. 6, (1923). 6) Maxwell, Reston \& Brucke: The effect of repeated rotation etc. Amer. Journ. Physiol. 8, 432, (1912). 7) Driffith: The decrease of after-nystagmus during repeated rotation. Laryngoscope 129, (1920).

8) Fischer \& Babcock: The reliability of nystagmus test. J. A.M.A. 72 : 779, (1919). 9) van Egmond, Groen \& Jongkees: The function of vestibular organ. $\mathrm{S}$. Karger, New-York, (1952)，10）星野・福田：特

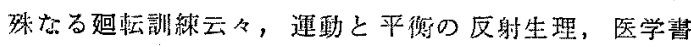
院，笨京，177，(1957). 11) Denker u. Kahler: Handbuch der Halsnasen u, Ohrenheilkunde,

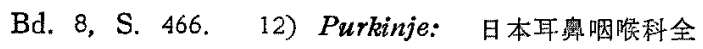
㶳，渎器，基礎㜊， I, 113. 13) Dohlmann: 日

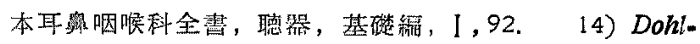
mann: Some practical \& theoretical points in labyrinthology. Proc. Roy. Soc. med. 28: 1371, (1935). 15) Huizinga: Ueber die Funktion des Bogengangsapparates usw., Archiv f.d. ges. Physiol. 231：525, (1933). 16) 小田：電気刺 戟飞因る聴器病変, 日耳渔, 33,409, (1927), 17) Oda: Observation on the pathology of impaired hearing etc, Laryngoscope 48, 765, (1938). 18) Oda: Pathologische Veraenderungen des Gehoerorgans usw, Arb. med. Fak. Okayama 1, 299, (1929). 19) Huizinga: Untersuchungen ueber die galvanische Retktion usw., Pfluegers. Arch. 224 : 564, (1920). 20) 石原：前庭器の電気刺戟に より起る人間の眼反応, 耳舆科, 福岡，13,5, (1920). 21) 石原: 前庭器の電気刺戟に上り起る家乘の眼反

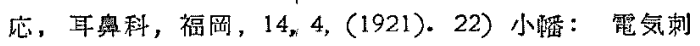

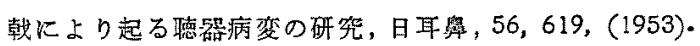
23）石川：迷路直流通電刺激による筋反忘，日耳鼻， 62 , 443, (1959). 24) Buddenbrock: Vergleichende Physiologie I, Sinnesphysiologie 305, (1952). 25) Marx, Experimentaer. Studienueber d. galvan. nystagmus. Z. f. Ohrenheilk. 63, (1911). 26) 本川: 電気生理学, 岩波霆店, 東京, S. 6 8, 24 26. 27) Pflueger: Physiologie d. Elektrotonus. Berlin, Hirschwald (1859). 28) Pfiueger: Ueber d. Tetanisierende Wirkung usw., Virchow. Arch. 3, 13, (1958). 29) Hoeber: Lehrbuch d. Physiologi d. Menschen. 334, (1922).

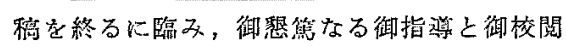
を睗つた福田教授に梁甚なる謝意を择げるとと 引に，終始御指尊御教示下さつた岩手医大榆教 授，本学㭙田助教授亚びに種々御協すいただ、 た教空貝の諸氏に榇心より感謝致します。

（原稿到着=昭和 35.1 .8 日急載） 